San Jose State University

SJSU ScholarWorks

Master's Projects

Master's Theses and Graduate Research

Spring 5-1-2021

\title{
The Permitting and Completion of Accessory Dwelling Units (ADUs) in Santa Clara County to Satisfy the Regional Housing Needs Allocation
}

Phuong Pham

San Jose State University

Follow this and additional works at: https://scholarworks.sjsu.edu/etd_projects

Part of the Infrastructure Commons, and the Policy History, Theory, and Methods Commons

\section{Recommended Citation}

Pham, Phuong, "The Permitting and Completion of Accessory Dwelling Units (ADUs) in Santa Clara County to Satisfy the Regional Housing Needs Allocation" (2021). Master's Projects. 987.

DOI: https://doi.org/10.31979/etd.2bgv-svy5

https://scholarworks.sjsu.edu/etd_projects/987

This Master's Project is brought to you for free and open access by the Master's Theses and Graduate Research at SJSU ScholarWorks. It has been accepted for inclusion in Master's Projects by an authorized administrator of SJSU ScholarWorks. For more information, please contact scholarworks@sjsu.edu. 
The Permitting and Completion of Accessory Dwelling Units (ADUs) in Santa Clara County to Satisfy the Regional Housing Needs Allocation:

A Program Analysis on the new State Law for

ADU Development that went into effect January 1, 2020

by

Phuong Pham

A Thesis Quality Research Project

Submitted in Partial Fulfillment of the

Requirements for the

Master's Degree

in

PUBLIC ADMINISTRATION

Professor Frances Edwards. Ph. D. Adviser

The Graduate School

San Jose State University

May 2021 


\section{Table of Contents}

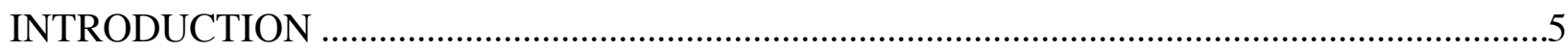

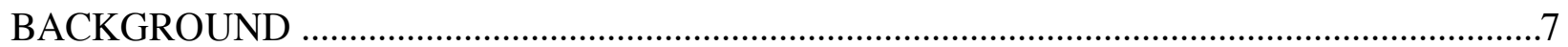

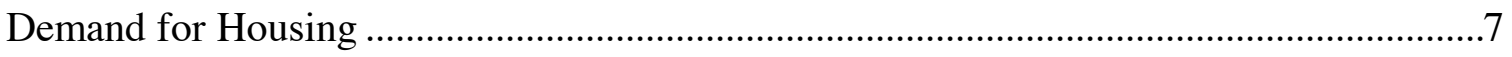

California Department of Housing and Community Development Guidance......................7 2015 to 2023 Regional Housing Needs Allocation for the 15 cities in Santa Clara County 9

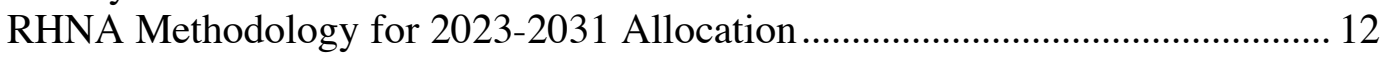

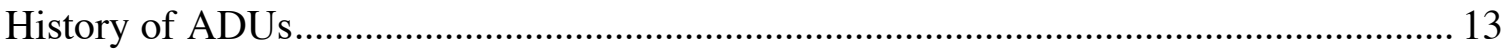

Senate Bill 1069, Assembly Bill 2299, Assembly Bill 2406 .............................. 15

Assembly Bill 68, Assembly Bill 881, Assembly Bill 670, Senate Bill 13 .......... 16

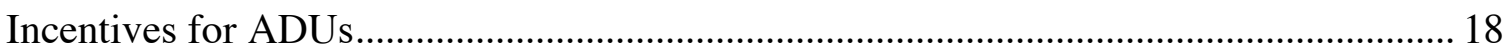

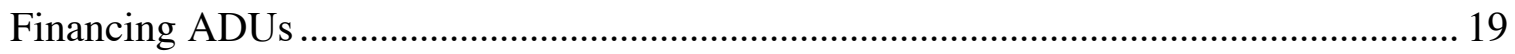

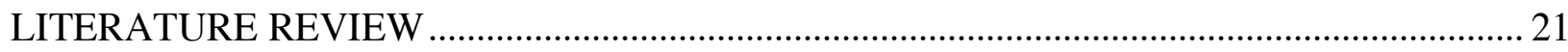

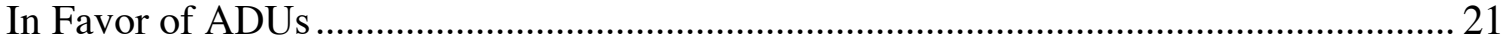

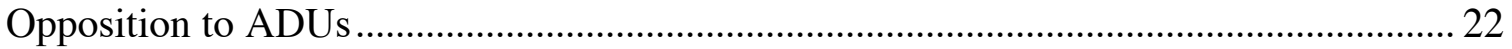

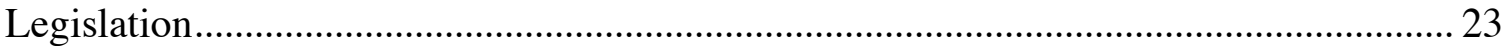

Ministerial and Discretionary Land Use Decisions ......................................... 24

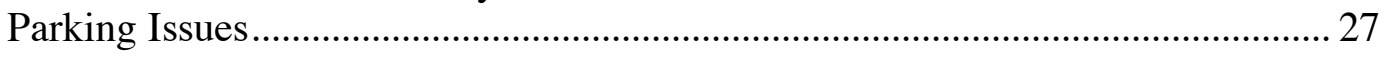

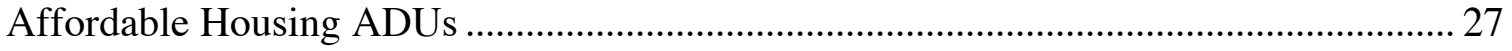

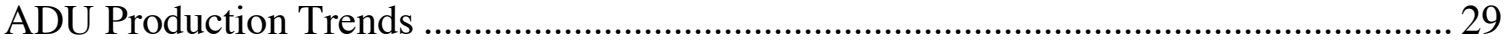

ADU program in City and County of Santa Cruz ................................................. 30

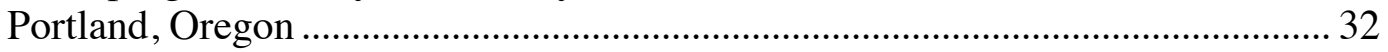

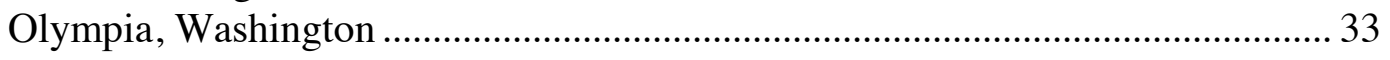

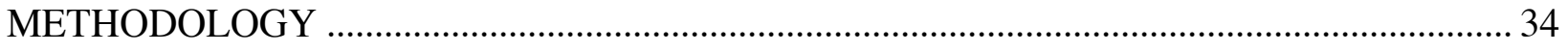

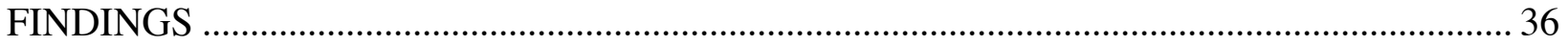

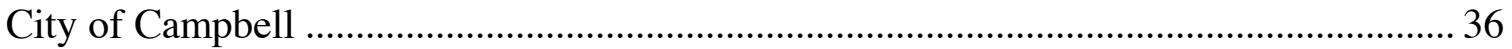

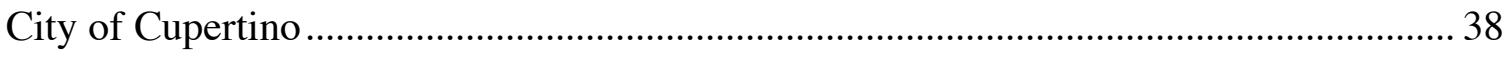

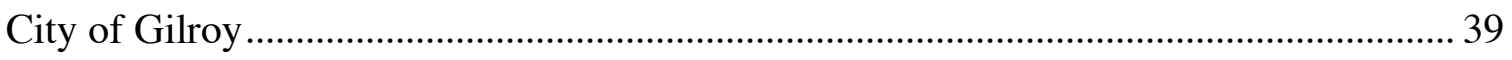

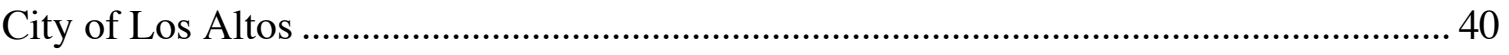

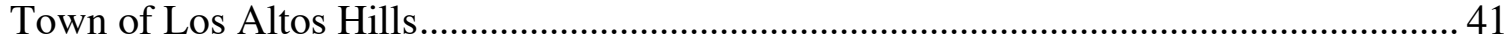

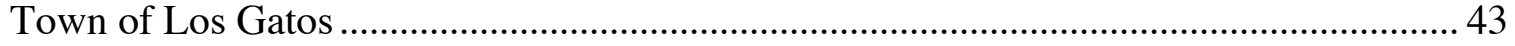

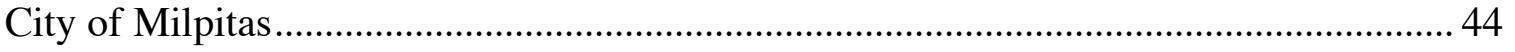

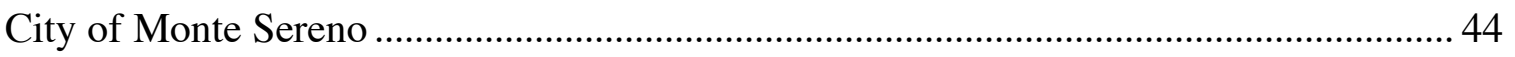

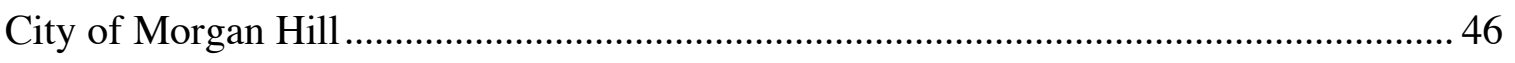




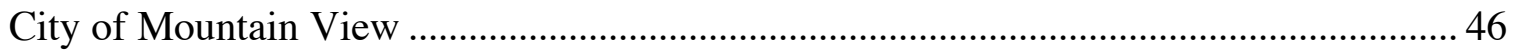

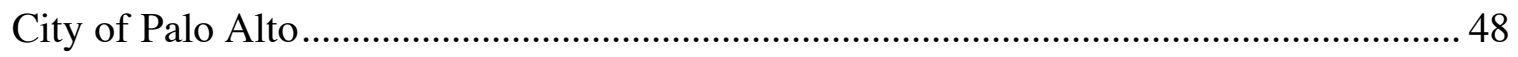

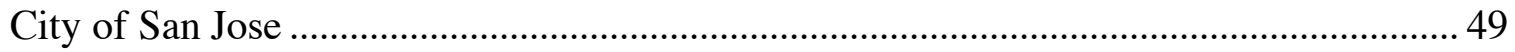

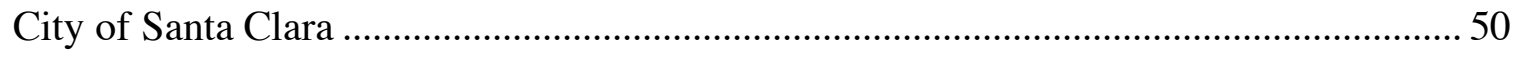

Santa Clara County ………………………………………………………………. 51

City of Saratoga

City of Sunnyvale …………………………………………………………………... 53

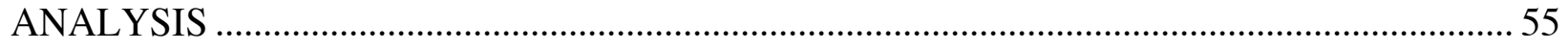

Updated Zoning Ordinance .......................................................................................... 55

ADU Program Webpage ………………………………………………………….... 56

ADU Plan Review Checklist ....................................................................................... 57

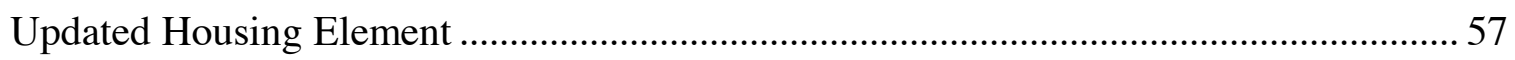

Incentive Programs .................................................................................................. 58

Progress Toward RHNA Goals ................................................................................... 59

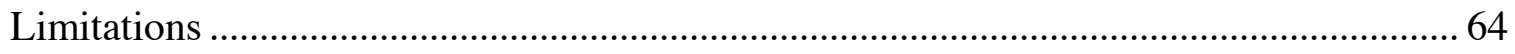

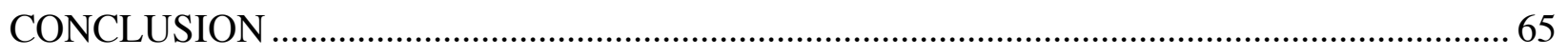

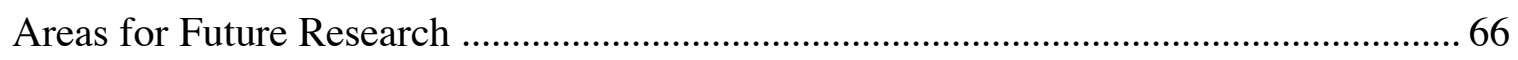

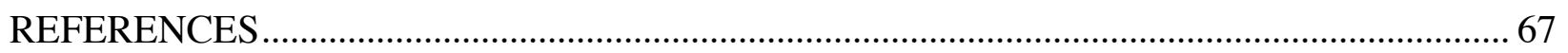




\section{List of Tables}

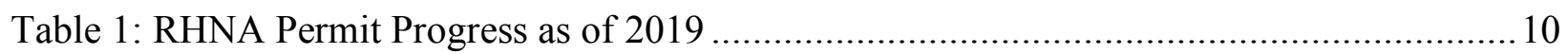

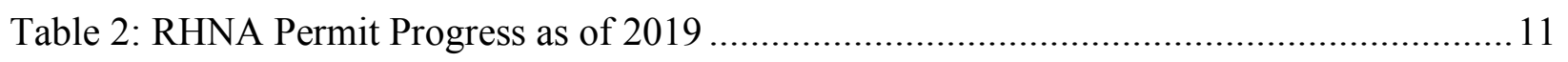

Table 3: 2015-2023 RHNA and Current Draft for 2023-2031 Allocation .............................. 13

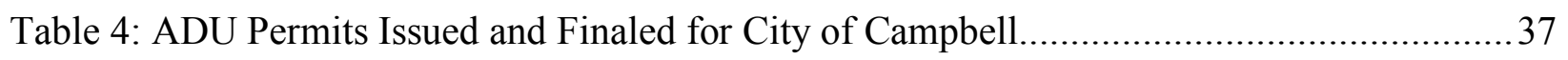

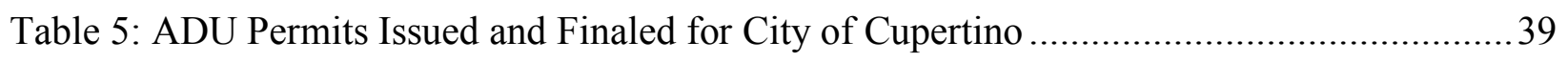

Table 6: ADU Permits Issued and Finaled for City of Gilroy .............................................4 40

Table 7: ADU Permits Issued and Finaled for City of Los Altos ...................................... 41

Table 8: ADU Permits Issued and Finaled for Town of Los Altos Hills................................ 42

Table 9: ADU Permits Issued and Finaled for Town of Los Gatos .......................................43

Table 10: ADU Permits Issued and Finaled for City of Milpitas...................................... 44

Table 11: ADU Permits Issued and Finaled for City of Monte Sereno ................................. 45

Table 12: ADU Permits Issued and Finaled for City of Morgan Hill......................................46

Table 13: ADU Permits Issued and Finaled for City of Mountain View ................................47

Table 14: ADU Permits Issued and Finaled for the City of Palo Alto ...................................48

Table 15: ADU Permits Issued and Finaled for City of San Jose .........................................50

Table 16: ADU Permits Issued and Finaled for the City of Santa Clara ...............................51

Table 17: ADU Permits Issued and Finaled for County of Santa Clara .................................52

Table 18: ADU Permits Issued and Finaled for City of Saratoga .......................................53

Table 19: ADU Permits Issued and Finaled for City of Sunnyvale ......................................54

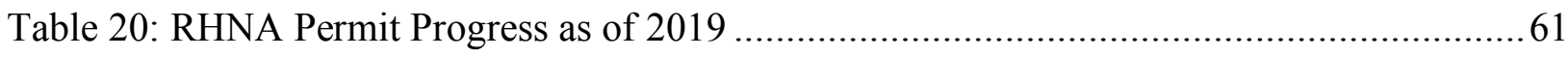

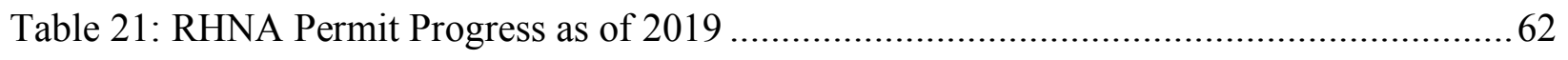

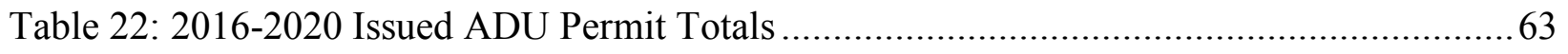




\section{INTRODUCTION}

California faces a severe affordable housing shortage which has been increasing at an alarming rate over the past three decades (O'Donnell, 2016). A lack of housing supply coupled with the rising cost of living has caused the housing inequality gap to widen (California Department of Housing and Community Development [HCD], 2018). The lack of housing supply has caused the cost of all types of housing to rise, leaving few affordable units for purchase or rent (Kimberlin, 2019), making the development of some alternative essential.

An accessory dwelling unit (ADU) is described as a residential space located on the same parcel as a primary dwelling unit. It can be attached or detached from the main residential home. It is smaller than the primary residential unit and must contain a kitchen, bathroom, and sleeping area (California Modulars, n.d.). ADUs were first legalized in California in 1982 through Senate Bill 1160, but the law lacked scope and specific details (Brinig \& Garnett, 2013). California began ramping up ADU permitting and regulation by passing several new laws in 2016 . The earliest statewide law that loosened ADU restrictions and encouraged ADU development was SB 1069, enacted in 2016. It required cities to adopt an ADU ordinance, required ministerial review ${ }^{1}$ of ADUs, and flexibility on parking requirements, among other changes (Chapple et al., 2020). On January 1, 2020, new ADU laws went into effect (AB 68, AB 881, and AB 670) that relaxed the limitations and streamlined obtaining ADU permits and construction in California. The legislative intent was to enlarge the stock of affordable dwellings to accommodate moderate to low-income households. The new laws clarified and improved various provisions to encourage

\footnotetext{
${ }^{1}$ Ministerial review means "ministerial approvals are those that involve little or no discretion, merely apply a checklist or clear requirements to the facts as presented" (Best, Best \& Krieger, 2020).
} 
the building of ADUs and now allowed junior accessory dwelling units (JADUs) on properties with an existing ADU (Chapple et al., 2020).

ADUs are an innovative strategy to address the housing shortage and are popular because they create extra income for homeowners and provide housing solutions that are more affordable for renters. ADUs represent a solution for supplying housing and managing urban sprawl by promoting infill development, increasing housing density, and decreasing a community's carbon footprint (Chapple et al., 2012). This study focuses on the role of ADUs for Santa Clara County's Regional Housing Needs Allocation (RHNA) goals and how ADUs have changed to comply with the newly implemented law on ADU development in California.

The research question for this study is as follows: How have the local jurisdictions in Santa Clara County changed their General Plans, the General Plan housing elements, and zoning ordinances to comply with the new state law on ADU development that went into effect on January 1, 2020? Can the creation of ADUs be counted as low-income housing units to contribute to achieving Santa Clara County's RHNA goals? 


\section{BACKGROUND}

\section{Demand for Housing}

California's population has been steadily increasing. Housing production was supposed to accommodate this by creating 180,000 units annually, but in the previous ten years, the annual housing production was less than 80,000 per year $(\mathrm{HCD}, 2018)$. The rising cost of housing is part of the reason for the housing shortage. The number of people moving to California for the robust technology industry impacted the housing shortage. With the influx of people moving to California due to job opportunities, the housing supply has not accommodated the growing population. The lack of affordable housing causes local governments concern across the state and affects people of all income levels (Kimberlin, 2019). The housing crisis is especially severe for those with lower incomes, disadvantaged communities, and young adults, as the demands and cost for housing are continually increasing (HCD, 2018), and they cannot compete against wealthier families. Other challenges contributing to California's housing shortage are the existing system for land-use planning and regulation, unstable funding for affordable homes, homelessness, and high housing production costs (HCD, 2018).

\section{California Department of Housing and Community Development Guidance}

California aims to address the housing needs for households of all economic levels by requiring each jurisdiction to allocate a certain number of housing units to each of the economic groups; this is executed through the general plan's housing element (HCD, n.d.-c). The California Department of Housing and Community Development (HCD) oversees Regional Housing Needs Allocation (RHNA) and housing elements that local governments must develop to address the need for various economic levels of housing (HCD, n.d.-c). California law mandates that every local jurisdiction in California must adopt a housing element as part of its General Plan to 
address every income level's housing need. The role of the housing element is to guarantee that local jurisdictions plan for enough housing to supply the housing needs for people in all income categories (HCD, n.d.-a). "The San José 2020 General Plan also includes a policy that affordable housing be distributed throughout the City of San Jose and not concentrated in any particular area or areas" (City of San Jose, n.d.).

\section{Regional Housing Needs Allocation}

The HCD determines the RHNA goals. The RHNA target is based on an analysis of each region's population demographics. HCD works in tandem with the council of governments in each area to divvy up allocation for each economic level in each region (HCD, n.d.-c). The RHNA predictions can be found in the housing element of each local jurisdiction. The housing element for each jurisdiction must detail their plans for providing homes for all income categories. The income categories that are in the housing-element law for RHNA are "Very Low (0-50\% of Area Median Income [AMI]), low (51\%-80\% of AMI), Moderate (81-120\% of AMI), and Above Moderate (over 120\% of AMI)" (HCD, n.d.-b). Each jurisdiction must show proof of the actual sales price, actual rents, subsidies, financing, or other housing affordability mechanisms to receive RHNA credit for housing units in each income level (HCD, n.d.-b). The housing element for each jurisdiction has details that demonstrate a record of land appropriate for development. The list includes vacant sites, potential sites for redevelopment, and an analysis that shows the zoning relationship to public facilities and services (HCD, n.d.-b). Based on this information, land suitable for residential development will be considered for new growth during the planning period. 
Tables 1 and 2 provide housing data for each of the cities in Santa Clara County, and their Regional Housing Needs Allocation for this current cycle of 2015 to 2023 . The data is from the HCD (2020) from their $5^{\text {th }}$ Cycle Annual Report Permit Summary and compiled by Silicon Valley at Home (HCD, n.d.-c). This data presents the current progress as of 2019 and the projected progress for this current cycle. Nearly every city has met its housing needs for the above moderate-income level category, but very few cities have met low-income and very lowincome categories. The cities that met the low-income categories were Gilroy and Morgan Hill. The only city to meet the very low-income category was Monte Sereno, their RHNA goal for very low-income was 23 , and as of 2019 , they issued 43 permits for units. 
Table 1: RHNA Permit Progress as of 2019

\begin{tabular}{|c|c|c|c|c|c|}
\hline \multicolumn{6}{|c|}{ 2015-2023 RHNA Permit Progress as of 2019} \\
\hline Jurisdiction & Affordability Level & $\begin{array}{r}\text { RHNA } \\
\text { Goal }\end{array}$ & $\begin{array}{c}\text { Permits as } \\
\text { of } 2019\end{array}$ & $\begin{array}{l}\text { Percent } \\
\text { Progress }\end{array}$ & $\begin{array}{c}\text { *Projected } \\
\text { Final }\end{array}$ \\
\hline \multirow[t]{5}{*}{ Campbell } & Very Low Income & 253 & 11 & $4 \%$ & $6 \%$ \\
\hline & Low Income & 138 & 4 & $3 \%$ & $4 \%$ \\
\hline & Moderate Income & 151 & 16 & $11 \%$ & $15 \%$ \\
\hline & Above Moderate & 391 & 407 & $104 \%$ & $144 \%$ \\
\hline & Total & 933 & 438 & $47 \%$ & $65 \%$ \\
\hline \multirow[t]{5}{*}{ Cupertino } & Very Low Income & 356 & 19 & $5 \%$ & $7 \%$ \\
\hline & Low Income & 207 & 0 & $0 \%$ & $0 \%$ \\
\hline & Moderate Income & 231 & 74 & $32 \%$ & $44 \%$ \\
\hline & Above Moderate & 270 & 215 & $80 \%$ & $110 \%$ \\
\hline & Total & 1064 & 308 & $29 \%$ & $40 \%$ \\
\hline \multirow[t]{5}{*}{ Gilroy } & Very Low Income & 236 & 63 & $27 \%$ & $37 \%$ \\
\hline & Low Income & 160 & 487 & $304 \%$ & $420 \%$ \\
\hline & Moderate Income & 217 & 24 & $11 \%$ & $15 \%$ \\
\hline & Above Moderate & 475 & 1124 & $237 \%$ & $327 \%$ \\
\hline & Total & 1088 & 1698 & $156 \%$ & $215 \%$ \\
\hline \multirow[t]{5}{*}{ Los Altos } & Very Low Income & 169 & 2 & $1 \%$ & $2 \%$ \\
\hline & Low Income & 99 & 28 & $28 \%$ & $39 \%$ \\
\hline & Moderate Income & 112 & 2 & $2 \%$ & $2 \%$ \\
\hline & Above Moderate & 97 & 535 & $552 \%$ & $761 \%$ \\
\hline & Total & 477 & 567 & $119 \%$ & $164 \%$ \\
\hline \multirow[t]{5}{*}{ Los Altos Hills } & Very Low Income & 46 & 13 & $28 \%$ & $39 \%$ \\
\hline & Low Income & 28 & 5 & $18 \%$ & $25 \%$ \\
\hline & Moderate Income & 32 & 4 & $13 \%$ & $17 \%$ \\
\hline & Above Moderate & 15 & 38 & $253 \%$ & $350 \%$ \\
\hline & Total & 121 & 60 & $\mathbf{5 0 \%}$ & $68 \%$ \\
\hline \multirow[t]{5}{*}{ Los Gatos } & Very Low Income & 201 & 0 & $0 \%$ & $0 \%$ \\
\hline & Low Income & 112 & 2 & $2 \%$ & $2 \%$ \\
\hline & Moderate Income & 132 & 53 & $40 \%$ & $55 \%$ \\
\hline & Above Moderate & 174 & 79 & $45 \%$ & $63 \%$ \\
\hline & Total & 619 & 134 & $22 \%$ & $30 \%$ \\
\hline \multirow[t]{5}{*}{ Milpitas } & Very Low Income & 1004 & 10 & $1 \%$ & $1 \%$ \\
\hline & Low Income & 570 & 0 & $0 \%$ & $0 \%$ \\
\hline & Moderate Income & 565 & 0 & $0 \%$ & $0 \%$ \\
\hline & Above Moderate & 1151 & 3221 & $280 \%$ & $386 \%$ \\
\hline & Total & 3290 & 3231 & $98 \%$ & $136 \%$ \\
\hline \multirow[t]{5}{*}{ Monte Sereno } & Very Low Income & 23 & 43 & $187 \%$ & $258 \%$ \\
\hline & Low Income & 13 & 1 & $8 \%$ & $11 \%$ \\
\hline & Moderate Income & 13 & 1 & $8 \%$ & $11 \%$ \\
\hline & Above Moderate & 12 & 30 & $250 \%$ & $345 \%$ \\
\hline & Total & 61 & 75 & $123 \%$ & $170 \%$ \\
\hline
\end{tabular}

Source: HCD 2019 Annual Progress Report Permit Summary provided by Silicon Valley at Home 
Table 2: RHNA Permit Progress as of 2019

\begin{tabular}{|c|c|c|c|c|c|}
\hline Morgan Hill & $\begin{array}{l}\text { Very Low Income } \\
\text { Low Income } \\
\text { Moderate Income } \\
\text { Above Moderate } \\
\text { Total }\end{array}$ & $\begin{array}{l}273 \\
154 \\
185 \\
316 \\
928\end{array}$ & $\begin{array}{r}41 \\
165 \\
136 \\
1200 \\
1542\end{array}$ & $\begin{array}{r}15 \% \\
107 \% \\
74 \% \\
380 \% \\
166 \%\end{array}$ & $\begin{array}{r}21 \% \\
148 \% \\
101 \% \\
524 \% \\
229 \%\end{array}$ \\
\hline Mountain View & $\begin{array}{l}\text { Very Low Income } \\
\text { Low Income } \\
\text { Moderate Income } \\
\text { Above Moderate } \\
\text { Total }\end{array}$ & $\begin{array}{r}814 \\
492 \\
527 \\
1093 \\
2926 \\
\end{array}$ & $\begin{array}{r}202 \\
170 \\
0 \\
3223 \\
3595 \\
\end{array}$ & \begin{tabular}{r|}
$25 \%$ \\
$35 \%$ \\
$0 \%$ \\
$295 \%$ \\
$123 \%$ \\
\end{tabular} & $\begin{array}{r}34 \% \\
48 \% \\
0 \% \\
407 \% \\
170 \% \\
\end{array}$ \\
\hline Palo Alto & $\begin{array}{l}\text { Very Low Income } \\
\text { Low Income } \\
\text { Moderate Income } \\
\text { Above Moderate } \\
\text { Total }\end{array}$ & $\begin{array}{r}691 \\
432 \\
278 \\
587 \\
1988 \\
\end{array}$ & $\begin{array}{r}43 \\
60 \\
42 \\
409 \\
554\end{array}$ & \begin{tabular}{r|}
$6 \%$ \\
$14 \%$ \\
$15 \%$ \\
$70 \%$ \\
$28 \%$ \\
\end{tabular} & $\begin{array}{r}9 \% \\
19 \% \\
21 \% \\
96 \% \\
38 \%\end{array}$ \\
\hline San Jose & $\begin{array}{l}\text { Very Low Income } \\
\text { Low Income } \\
\text { Moderate Income } \\
\text { Above Moderate } \\
\text { Total }\end{array}$ & $\begin{array}{r}9233 \\
5428 \\
6188 \\
14231 \\
35080\end{array}$ & $\begin{array}{r}1129 \\
231 \\
2304 \\
13392 \\
17056 \\
\end{array}$ & \begin{tabular}{r|}
$12 \%$ \\
$4 \%$ \\
$37 \%$ \\
$94 \%$ \\
$49 \%$
\end{tabular} & $\begin{array}{r}17 \% \\
6 \% \\
51 \% \\
130 \% \\
67 \% \\
\end{array}$ \\
\hline Santa Clara & $\begin{array}{l}\text { Very Low Income } \\
\text { Low Income } \\
\text { Moderate Income } \\
\text { Above Moderate } \\
\text { Total }\end{array}$ & $\begin{array}{r}1050 \\
695 \\
755 \\
1593 \\
4093 \\
\end{array}$ & $\begin{array}{r}131 \\
16 \\
54 \\
4008 \\
4209 \\
\end{array}$ & \begin{tabular}{r|}
$12 \%$ \\
$2 \%$ \\
$7 \%$ \\
$252 \%$ \\
$103 \%$ \\
\end{tabular} & $\begin{array}{r}17 \% \\
3 \% \\
10 \% \\
347 \% \\
142 \% \\
\end{array}$ \\
\hline Santa Clara Coun & $\begin{array}{l}\text { Very Low Income } \\
\text { Low Income } \\
\text { Moderate Income } \\
\text { Above Moderate } \\
\text { Total }\end{array}$ & $\begin{array}{r}22 \\
13 \\
214 \\
28 \\
277 \\
\end{array}$ & $\begin{array}{r}88 \\
0 \\
2597 \\
268 \\
2953 \\
\end{array}$ & $\begin{array}{r}400 \% \\
0 \% \\
1214 \% \\
957 \% \\
1066 \%\end{array}$ & $\begin{array}{r}552 \% \\
0 \% \\
1675 \% \\
1321 \% \\
1471 \% \\
\end{array}$ \\
\hline Saratoga & $\begin{array}{l}\text { Very Low Income } \\
\text { Low Income } \\
\text { Moderate Income } \\
\text { Above Moderate } \\
\text { Total }\end{array}$ & $\begin{array}{r}147 \\
95 \\
104 \\
93 \\
439 \\
\end{array}$ & $\begin{array}{r}0 \\
49 \\
14 \\
22 \\
85\end{array}$ & \begin{tabular}{r|}
$0 \%$ \\
$52 \%$ \\
$13 \%$ \\
$24 \%$ \\
$19 \%$
\end{tabular} & $\begin{array}{r}0 \% \\
71 \% \\
19 \% \\
33 \% \\
27 \% \\
\end{array}$ \\
\hline Sunnyvale & $\begin{array}{l}\text { Very Low Income } \\
\text { Low Income } \\
\text { Moderate Income } \\
\text { Above Moderate } \\
\text { Total }\end{array}$ & $\begin{array}{r}1640 \\
906 \\
932 \\
1974 \\
\mathbf{5 4 5 2}\end{array}$ & $\begin{array}{r}114 \\
21 \\
207 \\
2215 \\
2557\end{array}$ & $\begin{array}{r}7 \% \\
2 \% \\
22 \% \\
112 \% \\
47 \%\end{array}$ & $\begin{array}{r}10 \% \\
3 \% \\
31 \% \\
155 \% \\
65 \%\end{array}$ \\
\hline
\end{tabular}

Source: HCD 2019 Annual Progress Report Permit Summary provided by Silicon Valley at Home 


\section{RHNA Methodology for 2023-2031 Allocation}

Public meetings hosted by the Association of Bay Area Government's (ABAG) Housing Methodology Committee for the $6^{\text {th }}$ cycle to determine the RHNA for the Bay Area's 101 cities and nine counties started in October 2019 (Silicon Valley at Home, 2020-b). The Methodology Committee consists of members from the counties in the Bay Area. Members include elected personnel, housing and planning department staff, stakeholders, and a representative from the state (Silicon Valley at Home, 2020-b). Ten potential factors used to decide how to distribute housing include access to high-opportunity areas, job-to-home proximity, and the jobs-housing balance (Silicon Valley at Home, 2020-b). Table 3 is the draft as of September 2020 that the Methodology Committee agreed to submit to the ABAG committee for the RHNA 2023-2031 cycle. This table details the 2015 to 2023 very-low-income, low-income, and total RHNA targets, 2023-2031 draft of very-low-income, low-income, and the complete RHNA targets estimates. 
Table 3: 2015-2023 RHNA and Current Draft for 2023-2031 Allocation

\begin{tabular}{|c|c|c|c|c|c|c|}
\hline \multicolumn{7}{|c|}{$\begin{array}{r}\text { 2015-2023 Regional Housing Needs Allocation an } \\
\text { 2023-2031 Allocation (Sept. 2020) }\end{array}$} \\
\hline & \multicolumn{2}{|c|}{ 2015-2023 RHNA } & \multicolumn{2}{|c|}{ 2023-2031 Draft } & \multicolumn{2}{|c|}{ Percent Increase } \\
\hline Jurisdiction & VLI/LI & Total & VLI/LI & Total & VLI/LI & Total \\
\hline Campbell & 391 & 933 & 1,603 & 3,965 & $410 \%$ & $425 \%$ \\
\hline Cupertino & 563 & 1,064 & 2,551 & 6,223 & $453 \%$ & $585 \%$ \\
\hline Gilroy & 396 & 1,088 & 645 & 1,462 & $163 \%$ & $134 \%$ \\
\hline Los Altos & 268 & 477 & 914 & 2,267 & $341 \%$ & $475 \%$ \\
\hline Los Altos Hills & 74 & 121 & 219 & 544 & $296 \%$ & $449 \%$ \\
\hline Los Gatos & 313 & 619 & 824 & 1,938 & $263 \%$ & $313 \%$ \\
\hline Milpitas & 1,574 & 3,290 & 2,604 & 6,578 & $165 \%$ & $200 \%$ \\
\hline Monte Sereno & 36 & 61 & 81 & 191 & $224 \%$ & $313 \%$ \\
\hline Morgan Hill & 427 & 928 & 460 & 1,136 & $108 \%$ & $122 \%$ \\
\hline Mountain View & 1,306 & 2,926 & 4,533 & 11,381 & $347 \%$ & $389 \%$ \\
\hline Palo Alto & 1,123 & 1,988 & 4,055 & 10,058 & $361 \%$ & $506 \%$ \\
\hline San Jose & 14,661 & 35,080 & 25,828 & 66,521 & $176 \%$ & $190 \%$ \\
\hline Santa Clara & 1,745 & 4,093 & 4,758 & 12,047 & $273 \%$ & $294 \%$ \\
\hline Santa Clara County & 35 & 277 & 1,754 & 4,138 & $5010 \%$ & $1494 \%$ \\
\hline Saratoga & 242 & 439 & 877 & 2,100 & $362 \%$ & $478 \%$ \\
\hline Sunnyvale & 2,546 & 5,452 & 5,084 & 12,998 & $200 \%$ & $238 \%$ \\
\hline
\end{tabular}

Source: HCD 2019 Annual Progress Report Permit Summary and MTC Visualization Tool for RHNA Methodology and Allocation. Complied by Silicon Valley at Home

\section{History of ADUs}

An accessory dwelling unit (ADU) is defined by California law as a unit that can be detached or attached to an already existing single-family residentially zoned parcel (Cal. Gov. § 65852.2). ADUs are called by many names, such as "granny units," "granny flats," "secondary units," and "in-law units" (Brinig and Garnett, 2013). ADUs were popularized after World War II due to an increase in demand for housing (U.S Department of Housing and Urban Development [HUD], 2008). As the suburbs continued to develop in the 1950s and 1960s, the demand for low-density development also rose, leading to the local government prohibiting ADU construction (HUD, 2008). Despite the prohibition of ADUs, illegal ADUs were still being constructed in communities with a housing deficit (HUD, 2008). By the 1960s, San Francisco had 20,000 to 
30,000 ADUs, with about 90\% being illegally constructed (San Francisco Planning and Urban Research Association, 2006).

From the 1970s to the 1990s, some municipalities adopted ADU ordinances for permitting and development, but most of them were unsuccessful due to the lack of scope and accommodation (HUD, 2008). The first ADU law to pass in California was through Senate Bill 1160 in 1982 . SB 1160 allowed local jurisdictions to adopt zoning requirements to aid affordable housing production for seniors and low-income households, but it lacked specific details for ADU development (Brinig \& Garnett, 2013). In Santa Cruz, CA, they began proactively legalizing and encouraging ADU production to address affordable housing. Their original ADU ordinance dated back to 1984, which allowed secondary units on residential parcels greater than 5,000 square feet (Bhatt \& Ryan, 2015). By the early 2000s, they began expanding this ADU ordinance by encouraging homeowners to make the units affordable to low or very low-income renters by awarding fee waivers for permitting for those that do so. Other barriers for ADU permitting and construction was minimized by expanding residential zones and easing parking restrictions (Bhatt \& Ryan, 2015).

In 2003 the State approved Assembly Bill 1866 to modify local residential zoning laws to accept the new state guidelines (Brinig \& Garnett, 2013). AB 1866 required local jurisdictions to justify whether their zoning would comply with the latest state standards for ADUs (Brinig \& Garnett, 2013). Other provisions in $\mathrm{AB} 1866$ included making the maximum living square footage of ADUs be 1,200 square feet, required one parking space for each bedroom, allowed a maximum of two bedrooms, and permitted ADU construction only in single-family residential zones (Brinig \& Garnett, 2013). California recognized that secondary units have the potential to diversify their housing. As a provision of $\mathrm{AB} 1866$, it required that each jurisdiction in California 
have a ministerial process for approving ADUs (Chapple et al., 2020). ADUs began gaining popularity as an option for housing because they exemplified new urbanism by creating economic diversity and pedestrian-friendly neighborhoods (Ramsey-Mulsolf, 2018).

\section{Senate Bill 1069, Assembly Bill 2299, Assembly Bill 2406}

As California continued to struggle with providing housing to meet its growing population, legislators passed new bills to ease ADU regulations and promote ADU construction. In 2016, Senate Bill 1069, authored by State Senator Bob Wieckowski, was passed along with Assembly Bill 2299 (Bloom, 2016) and Assembly Bill 2406 (Thurmond, 2016). SB 1069 limited city authority to regulate accessory dwelling units statewide and removed some ADU development barriers. SB 1069 stated that a city's ADU ordinance would be voided if it conflicts with the new standards (S.B. 1069, 2016). The HCD has the power to regulate how local jurisdictions handle ADUs through SB 1069. SB 1069 explicitly referenced ADUs as a means to increase California's housing stock (S.B. 1069, 2016). SB 1069 amended several Government Code sections to replace the term "second unit" with "accessory dwelling unit" throughout the legislation. SB 1069 also removes parking standards imposed by AB 1866 (2003) and prohibited utility companies from charging ADUs for new residential use fees (S.B. 1069, 2016). The legislature also included improvements and incentives to aid and accelerate the construction of affordable housing (S.B. 1069, 2016). Local jurisdictions' housing elements, density bonus laws, and least cost zoning laws demonstrate the legislative intent of providing more affordable housing (S.B. 1069, 2016).

Assemblymember Richard Bloom authored Assembly Bill 2299, and it further streamlined ADU regulations across the state. AB 2299 allows local governments to adopt ADU ordinances with specifications that entail prohibiting the need for a passageway, eliminating 
some parking requirements if the ADU is near public transit, and prohibiting an ADU sale separately from the primary dwelling unit (A.B. 2299, 2016). The ADU's total floorplan cannot exceed 1,200 square feet, and the square footage for ADUs that are attached cannot exceed 50\% of the primary dwelling unit square footage (A.B. 2299, 2016). Ultimately, it is left up to the local agency to determine the minimum and maximum unit size requirements, minimum setbacks, and architectural review.

Assembly Bill 2406 was authored by Assemblymember Tony Thurmond and was passed in 2016. It addressed the construction of junior accessory dwelling units (JADU). AB 2406 allowed local jurisdictions to adopt JADU ordinances and for ADUs to be included in their housing element. The living square footage of JADUs is maximized at 500 square feet, and it must be contained within the primary residential dwelling unit (A.B. 2406, 2016). Local jurisdictions cannot deny JADU permitting based on parking requirements, as JADUs do not have any parking requirements (A.B. 2406, 2016).

SB 1069, AB 2299, and AB 2406 set statewide standards for permitting and constructing ADUs and JADUs, which local governments have to follow. Local jurisdictions can no longer prevent ADUs if they meet the provisions of state law. Following these laws' passage, ADU permitting and development began increasing and significantly impacted ADU production across the state (Chapple et al., 2020).

\section{Assembly Bill 68, Assembly Bill 881, Assembly Bill 670, Senate Bill 13}

Assembly Bill 68 authored by Assembly Member Phil Ting and Assembly Bill 881 written by Assembly Member Richard Bloom were signed into law by Governor Gavin Newsom in October 2019, requiring local agencies to respond to a permit application within two months of receiving it (Maclean, Golub \& Ashe, 2019). Before this legislation passed, the application review time 
was 120 days. This bill's goal was to make the process straightforward and streamlined for building an ADU on an already existing property. Reducing ADU approval requirements and having the opportunity to build a JADU in conjunction with the main ADU will likely incentivize homeowners to build ADUs. Furthermore, these laws remove some barriers, such as standards on lot coverage and minimum lot sizes (A.B. 68, 2019). Other details of this law include ADUs being allowed in multi-family buildings and allowing storage rooms and similar spaces to be converted to ADUs, provided building codes are met (Maclean, Golub \& Ashe, 2019).

The subsequent legislation that was passed was Assembly Bill 670 (Assembly Member Friedman). This legislation aimed to incentivize homeowners to build an ADU on their property and defined the land use for ADUs. Other details for AB 670 were that permitting fees were reduced, setback requirements minimized, parking requirements were taken out entirely, and restrictions on zoning districts for ADUs were relaxed. AB 670 allowed ADU zoning for multifamily residences and mixed-use neighborhoods (A.B. 670, 2019).

Senate Bill 13 was authored by Senator Wieckowski. It built upon recent updates to ADU and JADU legislation and established impact fee exclusions dependent on the ADU space (S.B. 13, 2019). ADUs less than 750 square feet are excluded from impact fees, and impact fees for ADUs larger than 750 square feet will be calculated relative to the relationship of the main dwelling unit (S.B. 13, 2019). These provisions have a sunset date to expire on January 1, 2025 (Maclean, Golub \& Ashe, 2019).

The recent ADU laws that passed authorize the HCD to inform the jurisdiction if they find that their ADU zoning ordinance is not updated with state legislation. These laws clarified that local jurisdictions could identify secondary units to satisfy RHNA goals (Maclean, Golub \& 
Ashe, 2019). The recent ADU laws also provide an opportunity for owners of unpermitted ADUs to bring them up to code and legalize them (Maclean, Golub \& Ashe, 2019). Bringing the units up to code will ensure that the ADU is safe for tenants to inhabit. The law also requires that local agencies include in their housing elements a program that encourages the permitting of ADUs that offer affordable rents for all income categories (Maclean, Golub \& Ashe, 2019). The legislation also mandates HCD to compile a list of state funding and incentive options to help property owners plan, construct, and obtain permits for affordable ADUs (Maclean, Golub \& Ashe, 2019).

\section{Incentives for ADUs}

As described by the Planning, Building, and Code Enforcement Department of San Jose, the benefits of an ADU include creating more feasible housing options for the public, providing an opportunity for homeowners for an extra stream of income, promoting development on existing land, and encouraging the use of public transit (City of San Jose, n.d.). Public awareness regarding this information can motivate homeowners to build ADUs. Incentives for ADUs can vary from a stream of income, fee waivers, loan programs, pre-fab designs, lowered permitting fees, and reduced construction costs (Chapple et al., 2020).

With the rise in demand for housing, often the motivation for ADUs stems from parents downsizing. Elderly parents can move into the smaller dwelling and give their children a larger residence with their growing families, or the ADU can be built for new families or young couples (Koones, 2019). The affordable housing shortage can motivate homeowners to build additional units in their lot to provide housing for those who may need it. The extra income from renting out the ADU can incentivize homeowners to invest in construction. For homeowners who 
have illegal ADUs, there are several opportunities that local jurisdictions offer to bring the ADU up to code. In some cases, the penalty fees will be waived (Lopez, 2020).

To boost San Jose's affordable housing supply, Mayor Sam Liccardo of San Jose has expressed his support for ADUs. To incentivize homeowners to build ADUs, he proposed a program that offers forgivable loans and waiving fees for homeowners willing to develop and rent out ADUs to disadvantaged individuals and households (DeRuy, 2019). Mayor Liccardo hopes that with this incentive, homeowners will be more inclined to build ADUs. The City of San Jose works with a vendor to offer pre-approved ADU designs that make the construction and permitting cheaper than for a custom-built ADU (City of San Jose, n.d.) According to San Jose Planning Director Rosalynn Hughey, "If homeowners rent out their unit at a maximum amount of $\$ 2,081$, they can qualify for a tax exemption from the city," such as waiving business license fees (Lopez, 2020). The City of San Jose also has a self-assessment checklist that details the program's eligibility and potential costs to help homeowners decide if they are interested in obtaining an ADU permit (City of San Jose, n.d.). Each of the 15 jurisdictions in Santa Clara County has its way of displaying information on its ADU program that is accessible for homeowners who are interested in obtaining a permit to build an ADU.

\section{Financing ADUs}

Despite the passage of the new laws for ADU production, the most significant barriers to building ADUs are the expenses. These costs are more of a burden to lower-income groups, and many cannot afford to build an ADU, despite ADUs being marketed as affordable housing. The average cost to build an ADU in California is $\$ 167,000$, and the average price to build an ADU in the Bay Area is $\$ 237,000$ to $\$ 400,000$ (Chapple et al., 2020). Other costs that homeowners are responsible for are permitting fees, impact fees, and utility fees. The prices associated with 
ADUs vary in each local jurisdiction. Options to finance an ADU are limited to programs and incentives that specific local jurisdictions can offer. There rarely exist loans to assist property owners in building ADUs. Most people fund ADUs with "cash, a home equity line of credit, or cash-out refinancing", or a renovation loan (Chapple et al., 2020). Obtaining these loans or having cash on hand is difficult to do for someone with a lower income, or for people who do not have the means to borrow against their property (Chapple et al., 2020).

Some programs in the Bay Area assist with financing ADUs. The Small Homes, Big Impact program, sponsored by the Silicon Valley Housing Trust, helps homeowners by offering educational workshops and financial assistance (Housing Trust Silicon Valley, n.d.). The program entails a thirty-six-month construction loan that is considered a second mortgage that can cover up to $\$ 200,000$ in construction costs (Housing Trust Silicon Valley, n.d.). HCD's CalHome program also offers funding to local public organizations for First-Time Homebuyer Mortgage Assistance and helps homeowners in the low- and very low-income category fund ADUs (Chapple et al., 2020). 


\section{LITERATURE REVIEW}

\section{In Favor of ADUs}

ADUs are gaining more recognition and acceptance as a feasible option for housing (Skinner, 2011). ADUs represent a step in the right direction for creative housing options. It is an option that promotes infill development, creates less impact on the environment, decreases the usage of utilities, and mitigates urban sprawl (Chapple et al., 2012). Contrary to beliefs that ADUs will cause overcrowding, residential homes and communities are changing to be more spread out now than they were forty years ago (Sanchez-Moyano \& Galante, 2016). The underutilized space in homes and communities motivates homeowners to build ADUs to make use of the area and get an extra stream of income (Sanchez-Moyano \& Galante, 2016). These secondary units are also an option for infill development. They provide low-density residential augmentation that stays hidden because it is typically built behind the primary dwelling units or attached to the primary dwelling unit. ADUs are generally not visible from the street, so there are relatively fewer neighbors' objections (Chapple et al., 2012).

The economic impact of ADUs can affect the private and public economies. ADUs provide homeowners an additional stream of income. The values of their homes are increased with the presence of ADUs, as it allows for more living space; this will boost local property tax for the single-family residential properties that have permitted ADUs (Chapple et al., 2012). The state benefits from the increased sales and income taxes from ADU development, while residents and the public benefit of the additional housing that ADUs provide to accommodate lower income levels. All of the existing ADUs that are nonpermitted represent foregone property tax revenue that could have been collected by the local jurisdiction, and also represent a safety hazard, as the living space may not be up to code (Chapple et al., 2012). Surveys suggest that 
adult children and their elderly parents prefer ADUs as their mode for housing so that the elderly parents can age in place and still be close with their family (Brinig \& Garnett, 2013).

In recent years, "new urbanist" architects and planners have been against single-family residential zoning (Brinig \& Garnett, 2013). They have been promoting land-use regulations inclusive of different residential zoning, including ADUs (Brinig \& Garnett, 2013). ADUs represent an option for housing that is more affordable and sustainable. Local agencies will need to encourage the development of ADUs by informing the public proactively about the option. This can be done by changing zoning to allow additional units to be permitted, refining minimum and maximum sizes of ADUs, minimizing review time, and updating regulations regarding lot size, if they want ADUs to be affordable in the long term (Davis, 2018).

\section{Opposition to ADUs}

Brinig and Garnett (2013) surveyed ADU legislative improvements undertaken in several states to analyze what encourages ADU production. Their research found that parochialism in the land use context has been a primary obstacle for increasing affordable housing supply in suburban jurisdictions (Brinig \& Garnett, 2013). Other concerns for ADUs stem from the not-in-mybackyard (NIMBY) group, because their neighborhood may lose its character with the community being more populated (Brinig \& Garnett, 2013). With an increase in ADU production, there is a possibility for growth in negative externalities associated with urban density, such as strained public services and infrastructure, overuse of water and sewer systems, and overuse of electricity utilities (Sanchez-Moyano \& Galante, 2016).

Other barriers to ADU production are the costs associated with permitting and developing an ADU. Financing an ADU can also be difficult for homeowners who already have a significant 
mortgage. Having an ADU on the property will increase property value and raise property taxes (Davis, 2018). Budgeting for ADU costs remains out of the reach of individuals and families of modest means, especially in areas with high real estate values and property taxes (Brinig \& Garnett, 2013). Funding ADUs may also be a cost burden for older Americans looking to downsize, especially those on fixed incomes. Creating incentives that help homeowners with the costs and fees of building ADUs, and waivers for impact fees, may garner support from homeowners to building ADUs.

\section{Legislation}

California first addressed ADUs in 1982 when it allowed local jurisdictions to have secondary units on their property. The 2003 amendment required that all reviews pertaining to ADUs be ministerial instead of discretionary. Before 2016, local jurisdictions had very little guidance and oversight from the state for ADU development (Basor, 2020). Previous zoning rules for singlefamily residential parcels caused a barrier for ADUs. Still, the increase in laws encouraging ADU creation has widened the scope for developing ADUs to increase the housing stock (Chapple et al., 2012). From 2016 to 2020, there have been great strides made in the permitting process and construction of ADUs that have made the process more accessible and provide homeowners with incentives to build ADUs.

The California Government Code now includes ADUs as an affordable housing type. Still, California policymakers acknowledge that ADUs are costly to build, and implore local jurisdictions to explore other financing options for their ADU program (Chapple et al., 2020). Assembly Bill 68 by Assemblymember Phil Ting details a plan to help homeowners qualify for loans to build ADUs on their property; this program is called "Help Homeowners Add New Housing Program” (Chapple et al., 2020). 
Homeowners in the low and moderate-income category are less likely than the abovemoderate income groups to know how to obtain an ADU permit (Chapple et al., 2020). There is a public interest in building ADUs; however, general information may not be readily available. Providing workshops to inform homeowners of their local ADU program can encourage and educate homeowners to garner more support in building ADUs (Chapple et al., 2020). The support for building ADUs can favor what was intended by the legislation. Local jurisdictions can gain public support by informing the public of their accessory dwelling unit programs and ease their permitting processes and zoning ordinance to be inclusive to people of all income levels (Chapple et al., 2020). Creating programs that assist with funding and promoting local homeowner education and outreach programs will help each local jurisdiction streamline its permit processing (Chapple et al., 2020). Chapple et al. (2020) recommended that local agencies create ADU programs that promote outreach and incentivize homeowners to build ADUs (2020). These strategies should be included in each local jurisdiction's next cycle of housing elements to overcome current housing limitations to guarantee that each municipality meets its statemandated targets for housing production under the RHNA process (Chapple et al., 2020).

\section{Ministerial and Discretionary Land Use Decisions}

Under the California Constitution, local agencies have the authority to make land-use decisions, which can be managed either as ministerial or discretionary actions (Thompson, 2009). Instances of ministerial decisions are 1) consent of a subdivision map that follows the proposed plan; 2) issuing a building permit that meets the building and zoning code regulations; 3) approving an ADU permit that meets the state's minimum restrictions, and in all cases where a checklist approach can be used to determine whether all requirements have been met. Discretionary landuse decisions can vary from development protocols, proposed subdivision, and zoning for land 
maps, "conditional use permits", scheduled unit developments, and "coastal development permits" (Thompson, 2009). Other land-use decisions that are discretionary require "judgment, deliberation, or decision" from the public to approve or disapprove an act (Thompson, 2009), which requires a more analytical approach. There has been an increase in the number of cases challenging land-use decisions.

HCD department recommended that ministerial approval of new construction can streamline the housing construction and increase housing opportunity across all economic levels (HUD, 2018). To promote more housing production, California Governor Gavin Newsom signed Senate Bill 330 to stop local agencies from allowing additional barriers to increasing the housing stock (Murphy, 2019). The law is scheduled to sunset on January 1, 2025. SB 330 amended the Housing Accountability Act and established a new ruling that housing developments in California "are subject to the ordinances, policies, development standards, and fees" effective when the homeowner or developer submits their application (Murphy, 2019). For parcels of land that allow housing, it "may not be downzoned, and specific land-use designations" cannot have more restrictions than what was allowed as of January 1, 2018 (Murphy, 2019).

There have been discussions about splitting the lot to create a separate parcel for ADUs, which would allow single-family properties to be separated to make the purchase and selling of ADUs an option (Chapple et al., 2020). Another facilitation of ADUs to be split is through Senate Bill 1120. SB 1120 proposed ministerial approval of a single-family lot being split to facilitate a maximum of two new units on single-family residential parcels; this bill is restricted by local rules and zoning guidelines (Chapple et al., 2020). "Creating a separate parcel entirely for new ADUs" can incentivize homeowners to obtain permitting for ADUs because 
"prospective residents of that ADU could purchase the lot ... and secure conventional financing through home construction loans or a purchase loan" (Chapple et al., 2020, p. 18). 


\section{Parking Issues}

Legislators and city planners view ADUs as a way to supply housing for the growing population and add to the housing stock. Local regulations that impose strict zoning ordinances, with requirements such as parking spaces, can significantly restrict the development of these additional units (Chapple et al., 2020). Secondary units in close proximity to public transit systems can reduce their parking requirements to encourage public transportation use and lessen the need for a car (Chapple et al., 2012). The availability of parking tends to be the main barrier when discussing high-density buildings, infill development, and ADU programs. Relaxed parking restrictions can encourage more ADU development, and in turn, can improve land-use policies to promote feasibility, sustainability, and fairness (HCD, 2018). In the recent ADU legislation, parking requirements were taken out entirely, which helped lower some barriers and restrictions to ADU development. However, a lack of onsite parking is apt to create neighborhood parking space scarcity.

\section{Affordable Housing ADUs}

Home developers in the 1910s and 1920s designed suburban homes to be increased an additional 25 to 40 feet, have similar setbacks, and have garages in the backyard to make the neighborhood appear to be less populated (Chapple et al., 2012). Due to the change in current demographics and present-day lifestyle, affordable housing looks toward secondary units to provide housing and additional means for homeowners to generate income (Chapple et al., 2012). Creative measures need to be taken to increase the housing stock to alleviate the housing shortage in California. One of the methods in doing so is ADUs, which tend to be built with a small footprint, while the current housing stock is occupied by people who prefer to age in place (Garcia, 2017). 
The development of secondary units as ADUs has occurred previously, but they tended to be unpermitted units that were not up to current building code regulations. Researchers have found that unpermitted housing units make up a sizable amount of the housing stock for lowerincome groups (Chapple et al., 2012). Studies done in Vancouver, British Columbia, determined that about ten to fifty percent of single-family rsidences had an additional unit. In Los Angeles county, a study focused on garage conversion units found that it accounted for 2.5 percent of the county's housing supply. In San Francisco, it is estimated that about eight percent of the city's housing supply was accounted for through unpermitted secondary units (Chapple et al., 2012). In a study done in 2011, Chapple et al. (2012) analyzed rental rates for secondary units from advertisements on Craigslist and compared this to rent amounts for each income category. It was found that the average ADU was rented at affordable rates to moderate-income categories for the East Bay Area. For the very low-income category, 30\% of secondary units on Craigslist were affordable to those households (Chapple et al., 2012). These findings demonstrate that ADUs can be accounted for in RHNA targets if the ADUs are up to code.

Although ADUs are being marketed as a solution to address the affordable housing crisis, no legislation caps the price at which homeowners rent out the ADUs in California. There is difficulty regulating ADUs as low-income housing units due to local jurisdictions having their standards and lack of agency oversight (Ramsey-Mulsolf, 2018). Homeowners are more inclined to rent out their properties at market rate instead of capping the price for low-income communities (Ramsey-Mulsolf, 2018). In Ramsey-Mulsolf's research of 57 random California cities, many places counted possible ADUs in their low-income category for housing needs. Still, none of these jurisdictions had upheld zoning criteria to ensure that the units became long-term housing for low-income individuals (Ramsey-Mulsolf, 2018). 


\section{ADU Production Trends}

Chapple, et al. (2020) have written about ADU programs in California and their permitting and building trends and financing options for making ADUs for low to moderate-income homeowners. Chapple et al. (2020) looked at data from 2018 and 2019 for ADU permitting and completions, and found that ADU activities in California increased with the passage of the updated ADU legislation during that time (Chapple et al., 2020). Jurisdictions across the state issued 5,911 permits in 2018, and in 2019 it was nearly tripled when they issued 15,571 permits (Chapple et al., 2020). Completed ADUs tend to lag in comparison to ADU permits due to the delayed construction time and delay in financing. Still, Chapple et al.'s (2020) research showed that completed ADUs more than tripled from 1,984 to 6,668 from 2018 to 2019 (Chapple et al., 2020). The counties that produced the most ADUs were Los Angeles, Santa Clara, and San

Diego. Her research found that ADU production also increased in the greater Sacramento region and the Central Valley region. These trends demonstrate that ADU developments are reaching other areas of California (Chapple et al., 2020).

Although there was an overall increase in ADU production throughout the years, Chapple et al.'s (2020) research data showed that ADUs are built primarily in affluent areas (2020). It was found that property owners who lived in more wealthy areas were more likely to acquire ADU permits and complete their construction projects than people in more disadvantaged communities (Chapple et al., 2020). For data representing the lower-income household category in the state, it was found that ADU permits and finalization of the permits tend to be delayed. In contrast, the above median income households in the state saw a disproportionate increase in permitting and completions of ADUs (Chapple et al., 2020). 
Other trends for ADU production include looking at neighborhoods based on home value. It was found that in the lower-income category, only two percent of property owners have applied for ADU permits or completed their construction among property owners in California. In comparison, about 40 percent of people in moderate-income groups and above who had obtained ADU permits completed the construction of their ADUs (Chapple et al., 2020). Other production trends demonstrate that ADU permitting was concentrated in California's affluent regions, such as Santa Cruz, California, and San Diego, California. Across the Bay Area, interest in ADUs has been taking place in wealthy areas. At the same time, other research showed that some lower-cost regions saw a rise in ADU permitting and construction in Southern California (Chapple et al., 2020). These findings demonstrate that California should address the issue of ADU financing that is apparent throughout all income levels. Although there was some disparity across the state, it was generally seen that there was more ADU activity in areas with higher home values. This suggests that the value of homes is encouraging ADU construction (Chapple et al., 2020).

\section{ADU program in City and County of Santa Cruz}

Basor (2020) wrote about comparing accessory dwelling unit programs in specific Bay Area jurisdictions to the City and County of Santa Cruz, which had a successful and long-standing ADU program. The reason for choosing the City and County of Santa Cruz was because their program had been around since the 1980 s, and it started with a basic framework for allowing ADUs (Basor, 2020). Santa Cruz is located on the coast of California, and mountains surround its landscape. It is close to the ocean, is a popular vacation destination and is home to the University of California at Santa Cruz, creating tenants for ADUs, making them a popular and environmentally conscious way to add to the housing stock in Santa Cruz (Skinner, 2011). 
In 2003, Santa Cruz passed a new law that amended city guidelines for secondary units. This ordinance eliminated prior parking requirements (Davis, 2018). The City of Santa Cruz was progressive and wanted to encourage the development of ADUs by waiving impact and other fees related to development for secondary units that were rented to low-income families (Davis, 2018). The city wanted to make the construction of secondary units more streamlined, so they created a detailed manual and plan set book that demonstrated ADU floor plans and designs created by local architects to make the process easier for homeowners (Davis, 2018). If homeowners chose a pre-approved plan from the plan set book, they could be approved for a building permit more quickly. The city also collaborated with the Santa Cruz Community Credit Union to provide low-interest pre-approved loans for secondary unit construction (Skinner, 2011).

Basor (2020) compared the accessory dwelling unit program in the County of Santa Cruz to the Counties of Alameda, Contra Costa, Marin, Santa Clara, and San Mateo. The cities analyzed were the Cities of Concord, Oakland, San Jose, San Mateo, San Rafael, with the City of Santa Cruz as the standard. For the findings, Basor looked at each specific jurisdiction's ADU program to analyze whether their policies restricted or incentivized ADU permitting. His data compared the number of permits issued annually from 2015 to 2019 and benchmarked this data to the City and County of Santa Cruz. His research found that all jurisdictions researched were mandated to revise their accessory dwelling unit zoning laws to reflect changes in California law effective 2019. Each jurisdiction saw an increasing trend for ADU permits. Each local jurisdiction had its own specific ADU development restrictions and incentives. From his research, he found that across the data, the most commonly used features of ADU ordinances were specific bedroom counts, living square footage limitations based on the primary home, and 
imposing local fees based on impact. The most frequently used incentive approach across all jurisdictions was a dedicated website to their ADU program, easily accessible ADU applications, and easily accessible public information on their ADU program. Other distinctive incentives that some programs offered included ADU financing programs, consultation assistance, and cost estimators (Basor, 2020).

From 2015 to 2019, Basor (2020) saw a constant increase in ADU permits issued. Year after year, since the implementation of ADU programs in Santa Cruz, there has been an increase in ADU permits and construction. The growth in permitting and completion of ADUs can be attributed to their incentives, loan programs, and outreach to the public. Other incentives that the City of Santa Cruz offered were pre-approved ADU floorplans and a manual with exact details for obtaining a permit for an ADU (Skinner, 2011).

\section{Portland, Oregon}

The City of Portland, Oregon, was the leader in secondary unit legislation and production. In 1997, their City Council passed several laws that permitted various types of secondary unit construction, allowing for increased minimum lot size, increased minimum floor size restrictions, and removed owner-occupancy restrictions (Davis, 2018). More recently, in 2010, Portland removed the mandatory fees for water and utility typically associated with new development to encourage more ADU production (Davis, 2018). Portland's strategy for ADU production has been shown to be successful. Portland had issued 24 ADU permits in 2000, and by 2016, that number had increased to 615 ; this number is comparable to the amount of building permits issued for new single-family homes (Davis, 2018). Based on the changes in legislation that provided financial incentives from 2010, the number of ADU permits increased rapidly. Since 2000, Portland has issued more than 2,000 secondary unit building permits (Davis, 2018). 


\section{Olympia, Washington}

Skinner (2011) did a case study about ADUs and Accessory Structures in Olympia, Washington, and compared it to Portland, Oregon, and other cities. He evaluated the ADU code's effectiveness in Olympia, Washington, and researched other cities with successful ADU programs and increased permitting of ADUs (Skinner, 2011). The reason he chose the city of Portland, Oregon, for comparison was that Portland had a long and progressive history of supporting the construction of ADUs, and there have been significant results from their ordinance (Skinner, 2011).

Skinner looked at the database for properties with ADUs and Accessory Structures in Olympia, Washington, from 2008 to 2010. Based on his research, it was revealed that there were many non-permitted ADUs in Olympia. This was comparable to the number of non-permitted dwelling units in Portland, Oregon (Skinner, 2011). The codes and permitting process were not clear and straightforward in Olympia, which was why there were many non-permitted dwelling units. Other issues that hindered ADU permitting were the lack of zoning classifications for dwelling units (Skinner, 2011). His recommendation was for the code to be amended to make the permitting process more streamlined and for the city to have incentive programs similar to Portland's to encourage more ADU development (Skinner, 2011). People will build ADUs based on demand for housing, whether or not there is legislation in place. The legislature should make the process more streamlined and have more incentives to encourage homeowners to build ADUs up to building code standards. 


\section{METHODOLOGY}

This study's research method will be a program evaluation described in the Program Planning and Evaluation for the Public Manager (Sylvia \& Sylvia, 2012). This research will be evaluating the problem of the lack of affordable housing in Santa Clara County (SCC) and the contribution of ADUs toward a solution. The research explored how SCC cities implemented their ADU ordinances and whether this incentivized the production of ADUs. The research evaluated whether implementing the new ADU laws, effective January 1, 2020, has added to the housing stock to satisfy RHNA goals for each city in Santa Clara County. The analysis considered which strategies improve the permitting of ADUs, and whether ADUs can fill the requirements for lowincome housing for the next RHNA cycle.

The data for this research was retrieved from public sources, specifically from the Planning, Building and Code Enforcement Department of each local jurisdiction in Santa Clara County. Data were collected from 2016 to 2020 regarding in which zones ADUs may be permitted, and how local jurisdictions updated their General Plan and Housing Element to enable ADUs. Data were also collected from 2016 to 2020 from the 15 cities in SCC for ADU permits and certificates of occupancy issued during those years. Additional data about ADU permits also came from The Center for Communication Innovation at UC Berkeley (CCI, n.d.).

Planning for the sixth RHNA cycle is happening now, and it is open for discussion from the public. Information regarding ADU development to accommodate all income levels will help strategize different methods to add to the housing stock and be used to evaluate the RHNA targets. This research will provide information to cities about various program elements that have led to successful ADU programs. The data that will be retrieved does not include information 
that pertains to human subjects or individually identifiable private information; therefore, it meets the requirements to be excluded from IRB review. 


\section{FINDINGS}

The research for this project provided insight into the number of ADU permits issued and finaled from 2016 to 2020 for all jurisdictions in Santa Clara County, and how each jurisdiction implemented its ADU program. Additional data was researched regarding the new ADU laws, effective January 1, 2020, which zones allowed ADUs, and how local jurisdictions have updated their General Plan and Housing Element to enable ADUs. The sources for data for this research included searching the internet, public data provided by the local jurisdiction, and contacting personnel from city and county jurisdictions. Other data were accessed from city and county websites, searching on city and county building permits pages, and researching the new ADU laws effective January 1, 2020. There may be some discrepancies with the numbers displayed for issued and finalized permits compared to the city or jurisdiction data. The differences are due to lack of information provided or human error with cross-referencing the data provided with the city or jurisdiction's database for the status of the finalized permits. This trend in data for issued and finaled ADUs is expected to be increasing to reflect the changing laws that encourage ADUs to be built. A complete table for ADU permits issued from 2016 to 2020 for all jurisdictions in Santa Clara County is provided in the analysis.

\section{City of Campbell}

The City of Campbell has an ADU fact sheet that summarizes their ADU program, their zoning restrictions, maximum unit size, parking requirements, design requirements, and frequently asked questions (City of Campbell, 2020). In their 2015 to 2023 General Plan, their Housing Element was updated in 2015 to include secondary units. Still, it has yet to be updated with the

recent ADU laws effective January 1, 2020 (City of Campbell, 2015). As a part of their Housing Element, secondary dwelling units were mentioned as a program to meet additional housing 
needs and a method for meeting RHNA goals. When these dwelling units were first introduced in the City of Campbell, there were stricter requirements. Some of the restrictions included 10,000 square feet minimum lot sizes, maximum living square footage was 640 square feet, and ADUs were only allowed in single-family zoning districts (City of Campbell, 2015). As a result, these restrictions limited the construction and popularity of ADUs in previous years. Although it was cited in their Housing Element that nine secondary dwelling unit permits were approved from 2009 to 2013, five secondary dwelling units were accounted for in the moderate-income category to meet RHNA goals (City of Campbell, 2015).

As the years went by, more ADU laws were passed to loosen the restrictions. The laws were meant to add to the housing supply and meet the housing needs to those of all income levels. As the ADU laws in California progressed, ADUs were brought to the attention of the public, and promoted the building and construction of ADUs. Their zoning ordinances were updated for accessory dwelling units to be allowed in single-family and multi-family zoned areas to reflect recent changes in the laws. There is now no minimum lot size, and now 500 square feet junior ADUs are permitted to be built in addition to an ADU (City of Campbell, 2020). Upon researching the permits issued and finaled from 2016 to 2020 for the City of Campbell, there was insufficient data, and it was only reported that there were about 40 permits issued in 2020 . The ADU permits issued were a combination of new ADUs, converted ADUs, and JADUs (B. Lennen, personal communication, March 4, 2021).

Table 4: ADU Permits Issued and Finaled for City of Campbell

\begin{tabular}{|l|c|c|c|c|c|c|c|c|c|c|}
\hline \multirow{2}{*}{ City/Jurisdiction } & \multicolumn{2}{|c|}{2016} & \multicolumn{2}{c|}{2017} & \multicolumn{2}{c|}{2018} & \multicolumn{2}{c|}{2019} & \multicolumn{2}{c|}{2020} \\
\cline { 2 - 10 } & Issued & Finalized & Issued & Finalized & Issued & Finalized & Issued & Finalized & Issued & Finalized \\
\hline Campbell & N/A & N/A & N/A & N/A & N/A & N/A & N/A & N/A & 40 & N/A \\
\hline
\end{tabular}

Source: City of Campbell, B. Lennen, personal communication, March 4, 2021 


\section{City of Cupertino}

The City of Cupertino acknowledged second dwelling units in their 2015 to 2023 General Plan and noted it as a way to supply housing to meet their RHNA goals (City of Cupertino, 2015). They forecasted that the city would approve an average of four secondary units each year. They estimate that over eight years, there will be thirty-two secondary dwelling units approved (City of Cupertino, 2015). The zoning allowed for the secondary dwelling units was on "single-family residential, residential hillside, agricultural, and agricultural, residential districts" (City of Cupertino, 2015). Additionally, it was reported that in the years of 2007 to 2013, there were thirty-one secondary units constructed that were implemented in their previous Housing Element (City of Cupertino, 2015). The City of Cupertino also has an ADU webpage that provides information to the public on what an ADU is, benefits that an ADU may provide, and a guideline for the process of obtaining an ADU permit to the final steps. Additional information that is provided to the public is an easily accessible fact sheet that provides answers to frequently asked questions regarding their ADU program. Their ADU webpage, fact sheet, and zoning ordinances were updated to reflect the recent changes in ADU law in 2020.

Some notable differences that the City of Cupertino implemented that are specific to their city are different sizing that depends on floor area ratio and lot coverage. Another notable difference is that the 1,200 square feet maximum size of the ADU is only allowed in multifamily zoning. In contrast, for single-family zoning, the maximum size an ADU can be is 1,000 square feet (City of Cupertino, 2020). Additional material on the City of Cupertino's robust landing page for their ADU program also includes information for financing options, programs, and workshops for interested homeowners (City of Cupertino, 2020). Public data for permits issued in the City of Cupertino only dated back partially to 2017, so data from 2016 and 2017 is 
skewed. This was provided publicly on their building permits webpage. The statuses of most of the issued ADU permits were published on their database as finaled. Still, the dates for some of the finaled permits were not noted and therefore not entirely clear, so the finaled permits for Cupertino may be inaccurate.

Table 5: ADU Permits Issued and Finaled for City of Cupertino

\begin{tabular}{|l|c|c|c|c|c|c|c|c|c|c|}
\hline \multirow{2}{*}{ City/Jurisdiction } & \multicolumn{2}{|c|}{2016} & \multicolumn{2}{c|}{2017} & \multicolumn{2}{c|}{2018} & \multicolumn{2}{c|}{2019} & \multicolumn{2}{c|}{2020} \\
\cline { 2 - 11 } & Issued & Finalized & Issued & Finalized & Issued & Finalized & Issued & Finalized & Issued & Finalized \\
\hline Cupertino & N/A & N/A & 1 & N/A & 7 & N/A & 11 & 3 & 16 & 7 \\
\hline
\end{tabular}

Source: City of Cupertino Building Department permits issued monthly report

\section{City of Gilroy}

The City of Gilroy first adopted its ADU ordinance in 2007 and streamlined its ADU process for efficiency for homeowners (City of Gilroy, 2020-b). The ADU program in the City of Gilroy is presented to provide housing stock and diversify housing opportunities. In the City of Gilroy's General Plan for 2040, they mention ADUs as an option in medium-density residential areas, such as townhomes or multifamily housing, and low-density residential areas of single-family homes (City of Gilroy, 2020-b). As a part of their updated General Plan, the City of Gilroy intends on promoting the production of secondary units in single-family residential areas by community outreach and educational materials (City of Gilroy, 2020-b). As their Housing Element was last updated in 2014, it does not reflect the recent changes in ADU law. Therefore, their zoning ordinance only allowed ADUs in single-family residential districts, and one parking spot was required per unit in their previous Housing Element (City of Gilroy, 2014). In their Housing Element for 2007 to 2014, it was cited that there were four ADU permits issued. In 2012, the City eliminated an architectural and site review for secondary units on the second floor of a home (City of Gilroy, 2014). 
The City of Gilroy has an updated webpage that reflects recent changes to ADU laws, helpful links for homeowners, the amount of ADUs allowed for different residential zoning, parking requirements, and design standards (City of Gilroy, 2020-a). The City of Gilroy also provides an ADU plan review checklist that states what is required to streamline the ADU process for homeowners and builders. In their updated zoning ordinance for ADUs, some differences that are noted here are that the maximum area size for ADUs allowed is 1,000 square feet, one additional parking space is required for the new unit, and junior ADUs of 500 square feet are permitted (City of Gilroy, 2020-a). The data for ADU permits issued were provided through personal communication with personnel from the City of Gilroy, and they were unable to give the number for finaled ADUs. The City of Gilroy saw an increasing trend of ADU permits issued from 2016 to 2020; this can be credited to recent changes in ADU law.

Table 6: ADU Permits Issued and Finaled for City of Gilroy

\begin{tabular}{|l|c|c|c|c|c|c|c|c|c|c|}
\hline \multirow{2}{*}{ City/Jurisdiction } & \multicolumn{2}{|c|}{2016} & \multicolumn{2}{c|}{2017} & \multicolumn{2}{c|}{2018} & \multicolumn{2}{c|}{2019} & \multicolumn{2}{c|}{2020} \\
\cline { 2 - 11 } & Issued & Finalized & Issued & Finalized & Issued & Finalized & Issued & Finalized & Issued & Finalized \\
\hline Gilroy & 4 & N/A & 7 & N/A & 7 & N/A & 11 & N/A & 13 & N/A \\
\hline
\end{tabular}

Source: City of Gilroy, H. Olmos, personal communication, February 23, 2021

\section{City of Los Altos}

The Housing Element of the General Plan (2015 to 2023) promoted second units as an affordable means for providing additional housing by implementing second dwelling regulations (City of Los Altos, 2015). In 2015, ADUs in the City of Los Altos were deed-restricted specifically for the low and very low-income category. From the years 2009 to 2014, there were eleven secondary units built. They expected the number of ADU permits to be increased, as the City planned on educating residents about second units and streamlining their ADU processes (City of Los Altos, 2015). Their previous zoning ordinance for ADUs allowed for a detached second dwelling unit to be permitted in single-family residential districts with at least a lot of 15,000 
square feet (City of Los Altos, 2015). This limited the available homes allowed to have an ADU because not many homes met this requirement. They have since updated their zoning ordinance to reflect the recent ADU changes effective January 1, 2020. Their zoning now has no minimum lot size, allows an attached or detached ADU to have the maximum 1,200 square feet, allows for the creation of a junior ADU of 500 square feet, one uncovered parking space, and minimum setback from the rear and side of four feet (City of Los Altos, 2020). The data researched regarding the number of permits issued and finaled in the City of Los Altos were through personal communications with the City Clerk. There was an increasing trend with the number of ADU permits issued and finaled, with the city issuing over three times the amount compared to 2018, which indicates that changing ADU laws that made obtaining an ADU permit more seamless led to the increase.

Table 7: ADU Permits Issued and Finaled for City of Los Altos

\begin{tabular}{|l|c|c|c|c|c|c|c|c|c|c|}
\hline \multirow{2}{*}{ City/Jurisdiction } & \multicolumn{2}{|c|}{2016} & \multicolumn{2}{c|}{2017} & \multicolumn{2}{c|}{2018} & \multicolumn{2}{c|}{2019} & \multicolumn{2}{c|}{2020} \\
\cline { 2 - 10 } & Issued & Finalized & Issued & Finalized & Issued & Finalized & Issued & Finalized & Issued & Finalized \\
\hline Los Altos & 2 & 1 & 3 & 1 & 9 & 4 & 31 & 13 & 22 & 15 \\
\hline
\end{tabular}

Source: City of Los Altos, A. M. Chelmengos, personal communication, April 15, 2021

\section{Town of Los Altos Hills}

The history of secondary dwelling units in the Town of Los Altos Hills date back to 1988, when the Housing Element stated that renting secondary dwelling units was allowed. Before this, the town only allowed secondary dwelling units to be occupied by relatives of property owners. Since removing this restriction, secondary dwelling units have been added to the rental housing supply (Town of Los Altos Hills, 2015). According to their 2015 to 2023 Housing Element, secondary dwelling units played a crucial role in providing additional affordable housing stock. From 2007 to 2014, 40 secondary dwelling units were constructed, of which 25 dwelling units 
supplied housing for extremely low and very low-income individuals (Town of Los Altos Hills, 2015). In their current Housing Element cycle, the town noted that secondary dwelling units supply most of their affordable housing allocation. Therefore, they plan to encourage and seek out programs to assist homeowners in constructing more ADUs (Town of Los Altos Hills, 2015).

The Town of Los Altos Hills has a specific ADU webpage with information about the updated ADU laws. This information is comparable to what is provided by the HCD. They also offer specific timelines for what is expected when homeowners apply for a permit to streamline the entire process. Their zoning laws have been updated to reflect the January 1, 2020 laws to permit the construction of JADUs, have fewer parking restrictions, such as one parking space required for a detached ADU, with the exception of the ADU being within half a mile of public transit (Town of Los Altos Hills, 2020). The Town of Los Altos Hills offers additional incentives for the additional floor area. If the detached ADU has a 30 feet setback and one parking space, it is allowed to be 1,200 square feet; if the JADU has an on-site parking space, it is allowed to exceed the 500 square feet maximum floor area by increasing to 650 square feet (Town of Los Altos Hills, 2020). The Town of Los Altos Hill's General Plan states that secondary dwelling units account for a number of their housing stock, especially for the extremely low to the very low-income group. However, data regarding issued and finaled permits for 2016 to 2020 could not be obtained publicly or through personal communication.

Table 8: ADU Permits Issued and Finaled for Town of Los Altos Hills

\begin{tabular}{|l|c|c|c|c|c|c|c|c|c|c|}
\hline \multirow{2}{*}{ City/Jurisdiction } & \multicolumn{2}{|c|}{2016} & \multicolumn{2}{c|}{2017} & \multicolumn{2}{c|}{2018} & \multicolumn{2}{c|}{2019} & \multicolumn{2}{c|}{2020} \\
\cline { 2 - 10 } & Issued & Finalized & Issued & Finalized & Issued & Finalized & Issued & Finalized & Issued & Finalized \\
\hline Los Altos Hills & N/A & N/A & N/A & N/A & N/A & N/A & N/A & N/A & N/A & N/A \\
\hline
\end{tabular}




\section{Town of Los Gatos}

In the adopted 2015 to 2023 Housing Element for the Town of Los Gatos, the Town introduced a program to expand secondary dwelling units by allowing them on properties over 10,000 square feet, on hillside residentially zoned lots of five acres or greater. These dwelling units had to be deed-restricted to offer rent at an affordable rate for lower-income renters (Town of Los Gatos, 2015). This was the town's method of creating incentives for homeowners to build secondary dwelling units. The town estimated that there were, on average, four ADU permits issued annually. This will encourage affordable housing in areas that did not have affordable housing options previously with their deed restrictions. Other incentives to their secondary unit program included waiving application fees for these affordable units with funding from the Below Market Price Housing In-lieu Fee Program (Town of Los Gatos, 2015). The Los Gatos Town Council approved their updated ADU ordinance on April 7, 2020, which expanded the zoning in which ADUs are allowed. They are now allowed in single-family residential, resource conservation, hillside residential, single-family residential downtown, duplex residential, and multi-family residential zoning, allowing for more options for homeowners interested in building ADUs. Affordable housing is spread throughout the town. Data for their issued and finaled ADU permits were provided from the Town of Los Gatos Building Permits public webpage.

Table 9: ADU Permits Issued and Finaled for Town of Los Gatos

\begin{tabular}{|l|c|c|c|c|c|c|c|c|c|c|}
\hline \multirow{2}{*}{ City/Jurisdiction } & \multicolumn{2}{|c|}{2016} & \multicolumn{2}{c|}{2017} & \multicolumn{2}{c|}{2018} & \multicolumn{2}{c|}{2019} & \multicolumn{2}{c|}{2020} \\
\cline { 2 - 11 } & Issued & Finalized & Issued & Finalized & Issued & Finalized & Issued & Finalized & Issued & Finalized \\
\hline Los Gatos & 1 & N/A & 3 & N/A & 4 & 5 & 8 & 5 & 6 & 2 \\
\hline
\end{tabular}

Source: Town of Los Gatos Building Department issued permits webpage 


\section{City of Milpitas}

The City of Milpitas stated in their 2015 to 2023 Housing Element that second units are permitted in single-family residential zoning areas. The restrictions include a one-bedroom maximum, maximum height of fifteen feet, and adherence to size and setback restrictions (City of Milpitas, 2015). The City of Milpitas has an updated website with information about different types of ADUs that are allowed to be permitted, fees for ADUs, ADU parking requirements, and a program called 'ADU Mondays' during which city staff can consult and familiarize residents with their ADU program. These are all incentives to encourage the production of ADUs.

Other updates to their ADU program were zoning changes. ADUs are now allowed in single-family residential and multi-family residential zones, and JADUs are allowed in singlefamily residential zones (City of Milpitas, 2020). Data for ADU permits issued and finaled were retrieved through personal communication with the City of Milpitas' Build Department personnel. ADU permits in the City of Milpitas were stagnant in 2016 and 2017, but in 2018 onwards there was a jump in permits issued and finalized, which could be due to public interest in ADUs and recent changes in ADU laws (B. Chan, personal communication, March 9, 2021).

Table 10: ADU Permits Issued and Finaled for City of Milpitas

\begin{tabular}{|l|c|c|c|c|c|c|c|c|c|c|}
\hline \multirow{2}{*}{ City/Jurisdiction } & \multicolumn{2}{|c|}{2016} & \multicolumn{2}{c|}{2017} & \multicolumn{2}{c|}{2018} & \multicolumn{2}{c|}{2019} & \multicolumn{2}{c|}{2020} \\
\cline { 2 - 10 } & Issued & Finalized & Issued & Finalized & Issued & Finalized & Issued & Finalized & Issued & Finalized \\
\hline Milpitas & 7 & 7 & 6 & 5 & 16 & 13 & 37 & 16 & 8 & 0 \\
\hline
\end{tabular}

Source: City of Milpitas, B. Chan, personal communication, March 9, 2021

\section{City of Monte Sereno}

The residential area of Monte Sereno is composed of low-density neighborhoods, and some of the homes come with detached or attached secondary dwelling units (City of Monte Sereno, 2015). In 2012, the City of Monte Sereno revised its ADU program to increase the living square footage of ADUs and remove the covered parking requirement. As of 2014, 87 second units 
provided affordable housing (City of Monte Sereno, 2015). Other revisions to their Second Unit Program include allowing these units to be 1,200 square feet, waiving fees for rent-restricted units, presenting public information about the Second Unit Program, and creating an amnesty program (City of Monte Sereno, 2015). Previously, there was only single-family residential zoning allowed in the City; multi-family residential zoning was recently established to diversify housing options in the City of Monte Sereno (City of Monte Sereno, 2015). These changes came before the recent ADU laws, that were effective in January 1, 2020, that allowed ADUs to be built in single-family and multi-family zones.

Every jurisdiction in California must consider ADUs to be permitted in single-family or multi-family zones. However, cities may limit where ADUs are allowed due to water, sewer, or public safety conditions. The new zoning laws for ADUs make the units more cost-efficient for homeowners by waiving impact fees for ADUs that are less than 750 square feet (City of Monte Sereno, 2020). The City of Monte Sereno provides a detailed ADU handbook that reflects all of the recent changes to ADU laws, information for why ADUs are needed, and how the city has adopted these changes to their zoning ordinance and Housing Element. Data for ADU permits issued and finaled could not be obtained through public resources or personal communication with the City.

Table 11: ADU Permits Issued and Finaled for City of Monte Sereno

\begin{tabular}{|c|c|c|c|c|c|c|c|c|c|c|}
\hline \multirow{2}{*}{ City/Jurisdiction } & \multicolumn{2}{|c|}{2016} & \multicolumn{2}{|c|}{2017} & \multicolumn{2}{|c|}{2018} & \multicolumn{2}{|c|}{2019} & \multicolumn{2}{|c|}{2020} \\
\hline & Issued & Finalized & Issued & Finalized & Issued & Finalized & Issued & Finalized & Issued & Finalized \\
\hline Monte Sereno & $\mathrm{N} / \mathrm{A}$ & $\mathrm{N} / \mathrm{A}$ & $\mathrm{N} / \mathrm{A}$ & $\mathrm{N} / \mathrm{A}$ & $\mathrm{N} / \mathrm{A}$ & N/A & $\mathrm{N} / \mathrm{A}$ & $\mathrm{N} / \mathrm{A}$ & $\mathrm{N} / \mathrm{A}$ & $\mathrm{N} / \mathrm{A}$ \\
\hline
\end{tabular}




\section{City of Morgan Hill}

In the City of Morgan Hill's 2035 General Plan, adopted in 2016, accessory dwelling units were allowed in low-density residential zones and medium-density residential zones (City of Morgan Hill, 2016). In their Housing Element, one of their options for increased housing is through the usage of ADUs, which can encourage alternative housing solutions and promote intergenerational housing (City of Morgan Hill, 2016). The City of Morgan Hill has a dedicated webpage for ADUs that contains a detailed brochure that reflects recent changes in ADU laws. Other resources on their ADU webpage include information on the engineering and utility division. This information is provided to determine whether the property might need encroachment permits, utility services, and impact fees. Fire department information is available to determine whether fire suppression systems are necessary. The building division provides information for submittal requirements and to bring an illegal second unit up to code (City of Morgan Hill, n.d.). Data for secondary dwelling units issued and finaled from 2016 to 2020 were retrieved through personal communication with personnel from the City of Morgan Hill. Much like other cities in Santa Clara County, ADU permits increased starting in 2018.

Table 12: ADU Permits Issued and Finaled for City of Morgan Hill

\begin{tabular}{|l|c|c|c|c|c|c|c|c|c|c|}
\hline \multirow{2}{*}{ City/Jurisdiction } & \multicolumn{2}{|c|}{2016} & \multicolumn{2}{c|}{2017} & \multicolumn{2}{c|}{2018} & \multicolumn{2}{c|}{2019} & \multicolumn{2}{c|}{2020} \\
\cline { 2 - 10 } & Issued & Finalized & Issued & Finalized & Issued & Finalized & Issued & Finalized & Issued & Finalized \\
\hline Morgan Hill & 2 & 2 & 5 & 1 & 15 & N/A & 10 & 7 & 4 & 4 \\
\hline
\end{tabular}

Source: City of Morgan Hill, E. Bassett, personal communication, February 22, 2021

\section{City of Mountain View}

The 2015 to 2023 Housing Element for the City of Mountain View was adopted in 2014, and they defined ADUs as companion units or secondary dwelling units as an option for affordable housing. These units were only permitted in single-family residential zones, and when the site is 35 percent greater than the minimum lot size required (City of Mountain View, 2014). Parking 
restrictions were previously required for each bedroom of the secondary unit. In the previous planning cycle, it was estimated that ten companion unit permits were issued. Still, it is unclear whether these units were deed-restricted for affordable housing (City of Mountain View, 2014). Other restrictions to their previous companion unit requirement included a maximum habitable floor area of 700 square feet and a maximum garage of 200 square feet (City of Mountain View, 2014).

The City has a dedicated ADU webpage with frequently asked questions, zoning updates, statewide legislative updates, and an informational guide with regulations. ADUs are now allowed to be constructed in single-family and multi-family zones with no minimum lot size requirement. A parking space is not required for multi-family ADU additions to reflect recent changes in ADU law, effective January 1, 2020 (City of Mountain View, 2020). Another incentive for homeowners to consider is that illegally constructed ADUs have a chance to be legalized by correcting all of the code violations through an ADU Amnesty Program administered by the City of Mountain View. The provisions of this program are available for illegally built ADUs from before December 31, 2019 (City of Mountain View, 2020). Data for ADU permits issued and finaled from 2016 to 2020 were obtained through the City of Mountain View's permit history webpage with data on issued and finaled permits. In the City of Mountain View's case, the rate at which ADU permits were issued was increased starting in 2018. In 2020, ADU permits were double that of 2018.

Table 13: ADU Permits Issued and Finaled for City of Mountain View

\begin{tabular}{|l|c|c|c|c|c|c|c|c|c|c|}
\hline \multirow{2}{*}{ City/Jurisdiction } & \multicolumn{2}{|c|}{2016} & \multicolumn{2}{c|}{2017} & \multicolumn{2}{c|}{2018} & \multicolumn{2}{c|}{2019} & 2020 \\
\cline { 2 - 11 } & Issued & Finalized & Issued & Finalized & Issued & Finalized & Issued & Finalized & Issued & Finalized \\
\hline Mountain View & N/A & N/A & 1 & N/A & 8 & N/A & 12 & 8 & 16 & 10 \\
\hline
\end{tabular}

Source: City of Mountain View permit history webpage 


\section{City of Palo Alto}

The City of Palo Alto amended its zoning ordinance to allow second units on single-family lots in 2017 (City of Palo Alto, 2017). The city's 2030 General Plan, adopted in 2017, allowed for second units to be built in single-family residential and village residential zones (City of Palo Alto, 2017). There are 32 secondary units accounted for in the RHNA that the City expects to be developed; these units are expected to accommodate the moderate-income group or below (City of Palo Alto, 2017). Other requirements that the City implemented were parking restrictions: units over 450 square feet were required to have two parking spaces, and units that were less than 450 sq. ft. only needed one parking spot (City of Palo Alto, 2017). The City of Palo Alto updated its zoning ordinance in accordance with the new laws effective January 1, 2020. Their ADU webpage has many resources for past and upcoming meetings regarding any changes made to their ADU program. The city also provides an ADU handout for easy access for residents to determine whether they are interested in building an ADU. In August of 2020, the city council discussed ways to improve their ADU program to enable affordable ADUs. The proposed ordinances differed from the state law that would encourage more ADU development in the City of Palo Alto. The staff proposed these changes after surveying applicants about the ADU/JADU ordinance and process (City of Palo Alto, 2020). The data for ADU permits issued and finaled from 2016 to 2020 for the City of Palo Alto came from their City Council meeting on ADUs (City of Palo Alto, 2020). The City of Palo Alto saw an increasing trend for ADU permit applications and saw a growing trend in garage conversions (City of Palo Alto, 2020).

Table 14: ADU Permits Issued and Finaled for the City of Palo Alto

\begin{tabular}{|l|c|c|c|c|c|c|c|c|c|c|}
\hline \multirow{2}{*}{ City/Jurisdiction } & \multicolumn{2}{|c|}{$\mathbf{2 0 1 6}$} & \multicolumn{2}{c|}{$\mathbf{2 0 1 7}$} & \multicolumn{2}{c|}{$\mathbf{2 0 1 8}$} & \multicolumn{2}{c|}{2019} & \multicolumn{2}{c|}{2020} \\
\cline { 2 - 11 } & Issued & Finalized & Issued & Finalized & Issued & Finalized & Issued & Finalized & Issued & Finalized \\
\hline Palo Alto & 5 & 4 & 12 & 9 & 35 & 12 & 62 & 33 & 13 & 23 \\
\hline
\end{tabular}

Source: City of Palo Alto, Item \#8 City Council Meeting, October 5, 2020 


\section{City of San Jose}

In 1982, when the first Statewide ADU laws were introduced, they allowed the construction of second units. Still, there was local flexibility for specific design standards, parking restrictions, minimum size requirements, and development standards (City of San Jose, 2015). The City of San Jose prohibited secondary units in 1984 due to issues with traffic, infrastructure, and safety concerns (City of San Jose, 2015). The City revisited secondary units in 2005 and created a Secondary Unit Pilot Program that led to a permanent secondary unit ordinance adopted in 2008 (City of San Jose, 2015). Its initial criteria required ADUs to be in single-family zoned districts; the minimum lot size was 6,000 square feet for attached ADUs. For detached ADUs, the minimum lot size was 8,000 square feet, the ADU had maximum square footage of 400 , and it required one parking space (City of San Jose, 2015). As of 2014, the City facilitated 140 secondary units and planned on updating its zoning ordinance to encourage more ADU development. This fits in with the City's Envision San Jose 2040 General Plan to supply housing and increase and improve their secondary unit program (City of San Jose, 2015).

In 2016 when ADU laws were beginning to relax ADU restrictions, the City of San Jose saw an increase in ADU permits issued and finaled, with 415 ADU permits issued in 2019 and 377 ADU permits issued in 2020. The City has an ADU webpage that is updated frequently with changes in ordinances. There is information on preapproved designs, their ADU Amnesty Program, the plan and review process for their program, fees that may apply, and other frequently asked questions (City of San Jose, n.d.). Additional information provided to the public is an Accessory Dwelling Unit Handbook and an ADU Universal Checklist that reflects state law requirements to make the process more streamlined for homeowners and developers. The data 
for ADU permits were obtained through personal communication with personnel from the Building Department of the City of San Jose.

Table 15: ADU Permits Issued and Finaled for City of San Jose

\begin{tabular}{|l|c|c|c|c|c|c|c|c|c|c|}
\hline \multirow{2}{*}{ City/Jurisdiction } & \multicolumn{2}{|c|}{$\mathbf{2 0 1 6}$} & \multicolumn{2}{c|}{$\mathbf{2 0 1 7}$} & \multicolumn{2}{c|}{$\mathbf{2 0 1 8}$} & \multicolumn{2}{c|}{2019} & \multicolumn{2}{c|}{2020} \\
\cline { 2 - 12 } & Issued & Finalized & Issued & Finalized & Issued & Finalized & Issued & Finalized & Issued & Finalized \\
\hline San Jose & 39 & 5 & 94 & 30 & 189 & 84 & 415 & 185 & 377 & 237 \\
\hline
\end{tabular}

Source: City of San Jose, J. Aguilar, personal communication, March 10, 2021

\section{City of Santa Clara}

The City of Santa Clara's previous Housing Element defined accessory unit as an additional dwelling unit that cannot exceed 640 square feet in floor area. This unit may be attached to a single-family unit or detached from a single-family unit (City of Santa Clara, n.d.). The City of Santa Clara allowed for second units to be built in single-family residential zones on parcels greater than 7,000 square feet since 2007. Since the implementation of their ADU program, there have been about 200 accessory unit permits issued in the city (City of Santa Clara, n.d.). As detailed in their Housing Element, the city planned to promote public interest in accessory units by revising their zoning ordinance to increase the city's housing stock.

The city also has an ADU webpage that has been updated to include new state legislation for ADU and JADU laws for interested homeowners. Some of the significant changes of these laws include allowing the construction of both an ADU and JADU on the same lot, allowing ADUs to be constructed in multi-family zones, and reducing the required setbacks so more properties can be qualified to build an ADU. The city also provides an ADU and JADU handout sheet that summarizes how the changes in state law will be reflected in the City's zoning ordinance. ADUs and JADUs are subject to ministerial approval on single-family and multifamily lots as long as it meets the detailed criteria on the handout. In their 2015 to 2023 Housing Element, the city had a goal of issuing 25 permits annually over eight years or 200 units over an 
eight-year period. Data for ADU permits issued in the City of Santa Clara were provided through a public records request. This data was cross-referenced with the city's building permits page to see finaled dates for the issued permits. Permits for ADUs began to increase starting in 2017 and have been increasing ever since. They are on track to issuing on average of 25 permits annually.

Table 16: ADU Permits Issued and Finaled for the City of Santa Clara

\begin{tabular}{|l|c|c|c|c|c|c|c|c|c|c|}
\hline \multirow{2}{*}{ City/Jurisdiction } & \multicolumn{2}{|c|}{2016} & \multicolumn{2}{c|}{2017} & \multicolumn{2}{c|}{2018} & \multicolumn{2}{c|}{2019} & \multicolumn{2}{c|}{2020} \\
\cline { 2 - 10 } & Issued & Finalized & Issued & Finalized & Issued & Finalized & Issued & Finalized & Issued & Finalized \\
\hline Santa Clara & 4 & N/A & 15 & 9 & 20 & 10 & 30 & 18 & 31 & 24 \\
\hline
\end{tabular}

Source: City of Santa Clara, public records request, March 1, 2021

\section{Santa Clara County}

In their 2015 to 2022 Housing Element, Santa Clara County wrote that secondary dwellings were accounted for to meet RHNA goals for the very low-income category. Secondary units averaged about 12 units built per year from 1999 to the present, and from 2007 to 2012, 50 secondary unit permits were issued (County of Santa Clara, 2014). To facilitate their secondary dwelling program, the county eliminated the requirement of secondary units being attached to the primary residence, increased the square footage of ADUs on smaller lots, and eliminated owneroccupancy requirements for secondary units on lots greater than 2.5 acres (County Santa Clara, 2014). Other information in the Housing Element determined that most affordable housing in unincorporated areas was supplemented by ADUs and farmworker housing (County of Santa Clara, 2014). Current zoning for these secondary units in Santa Clara County has been updated to reflect the recent changes in ADU laws. Accessory dwelling units are allowed in zoning districts that allow residential use, and the maximum floor size is 1,200 sq. $\mathrm{ft}$. for ADUs, a 500 sq. ft. JADU is allowed, and minimum setbacks have been reduced (County of Santa Clara. 2020). 
The county has an ADU webpage with basic facts and resources for ADUs. Additional staff reports and zoning ordinances detail updated information to effectively reflect the new ADU laws on January 1, 2020. Data for permits issued and finalized were obtained through personal communication with personnel from the Building Department from the County of Santa Clara.

Table 17: ADU Permits Issued and Finaled for County of Santa Clara

\begin{tabular}{|c|c|c|c|c|c|c|c|c|c|c|}
\hline \multirow{2}{*}{ City/Jurisdiction } & \multicolumn{2}{|c|}{2016} & \multicolumn{2}{c|}{2017} & \multicolumn{2}{c|}{2018} & \multicolumn{2}{c|}{2019} & \multicolumn{2}{c|}{2020} \\
\cline { 2 - 10 } & Issued & Finalized & Issued & Finalized & Issued & Finalized & Issued & Finalized & Issued & Finalized \\
\hline Santa Clara County & 2 & N/A & 3 & N/A & 27 & N/A & 34 & 26 & 53 & 20 \\
\hline
\end{tabular}

Source: County of Santa Clara, M. Martinez, personal communication, March 15, 2021.

\section{City of Saratoga}

The City of Saratoga has a floor area and site coverage bonus of providing a 10 percent increase given when units are deed-restricted for below-market-rate units. Since 2001, there have been about 41 second dwelling units built, of which 20 were deed-restricted (City of Saratoga, 2014). In the 2007-2014 Housing Element cycle, 22 second dwelling units were built (City of Saratoga, 2014). Similar to other cities in Santa Clara County, these second dwelling units were only allowed in single-family residential zones.

To reflect recent changes in ADU laws, the City of Saratoga updated its ADU webpage to keep residents updated with the changes and allow homeowners to know whether their property qualifies for an ADU. For single-family residential zoning, one ADU and one junior ADU are permitted, and on multi-family residential zoning, up to two detached ADUs are allowed (City of Saratoga, n.d.). Other information provided on their ADU webpage includes their permitting process, the process of legalizing existing ADUs, and a summary of design and development standards. Data for issued permits for secondary dwelling units were found through the City of 
Saratoga's Building Permit Activity Reports; then, this data was cross-referenced with the City's Permit Search page to determine the status of the issued permits.

Table 18: ADU Permits Issued and Finaled for City of Saratoga

\begin{tabular}{|l|c|c|c|c|c|c|c|c|c|c|}
\hline \multirow{2}{*}{ City/Jurisdiction } & \multicolumn{2}{|c|}{2016} & \multicolumn{2}{c|}{2017} & \multicolumn{2}{c|}{2018} & \multicolumn{2}{c|}{2019} & \multicolumn{2}{c|}{2020} \\
\cline { 2 - 11 } & Issued & Finalized & Issued & Finalized & Issued & Finalized & Issued & Finalized & Issued & Finalized \\
\hline Saratoga & 13 & 2 & 20 & 6 & 12 & 14 & 27 & 14 & 39 & 12 \\
\hline
\end{tabular}

Source: City of Saratoga Building Department

\section{City of Sunnyvale}

The City of Sunnyvale credits secondary dwelling units as an option to expand the housing stock on its limited developable land, and provide affordable housing that is spread throughout the city (City of Sunnyvale, 2014). For their Housing Element, the city planned on facilitating the construction of ADUs by providing public information on how to obtain building permits. The City of Sunnyvale allowed ADUs when AB 1866 was effective in July 2003; this allowed cities to impose development and design standards for their ADU program (City of Sunnyvale, 2014). Previously, the City of Sunnyvale allowed accessory dwelling units to be built in single-family residential zones; the maximum area of the ADUs was 700 sq. ft., and minimum lot sizes of 9,000 sq. ft. were required for design standards (City of Sunnyvale, 2014). Between the years 2007 to 2014, 17 accessory dwelling units were permitted (City of Sunnyvale, 2014). The City of Sunnyvale updated its zoning ordinance to reflect recent ADU laws and include other specific design standards that pertain to the city. For example, the city allows something called a "standard accessory dwelling unit" similar to a junior ADU. It is a smaller living unit that uses the interior space of the existing single-family home (City of Sunnyvale, 2021).

The city does not have a dedicated ADU web page, but they provide an ADU fact sheet and a checklist for homeowners interested in what their ADU program entails. This fact sheet includes information on design standards, development standards, possible fees, zoning 
ordinances, and additional information regarding the building permit process. Data for ADU permits issued were retrieved through personal communication with personnel from the Building Department of the City of Sunnyvale. This data was cross-referenced with the City's Permit Search page to determine the status of the issued permits.

Table 19: ADU Permits Issued and Finaled for City of Sunnyvale

\begin{tabular}{|l|c|c|c|c|c|c|c|c|c|c|}
\hline \multirow{2}{*}{ City/Jurisdiction } & \multicolumn{2}{|c|}{2016} & \multicolumn{2}{c|}{2017} & \multicolumn{2}{c|}{2018} & \multicolumn{2}{c|}{2019} & \multicolumn{2}{c|}{2020} \\
\cline { 2 - 10 } & Issued & Finalized & Issued & Finalized & Issued & Finalized & Issued & Finalized & Issued & Finalized \\
\hline Sunnyvale & 3 & N/A & 4 & 3 & 21 & 5 & 44 & 20 & 45 & 32 \\
\hline
\end{tabular}

Source: City of Sunnyvale, L. Rodriguez, personal communication, February 16, 2021 


\begin{abstract}
ANALYSIS
The Findings provide data regarding whether the implementation of the new ADU laws, effective January 1, 2020, has added to the affordable housing stock to satisfy RHNA goals for local jurisdictions in Santa Clara County. The analysis considers which strategies improved the permitting of ADUs, and whether ADUs can fill the requirements for low-income housing for the next RHNA cycle. The analysis compares the number of ADU permits issued and finaled from 2016 to 2020 of all the jurisdictions in Santa Clara County to the RHNA goals for each of the cities. All local jurisdictions in Santa Clara County have their ADU programs and have updated their zoning ordinances to reflect the new ADU laws effective January 1, 2020. However, some cities have specific criteria that pertain to their jurisdiction.
\end{abstract}

Every city in Santa Clara County saw an increase in ADU permits issued throughout the years as state ADU laws began to relax local requirements. Because ADUs are often rented out to family members $(16 \%)$, acquaintances, friends $(2 \%)$, or household employees, serve as home offices or studios (16\%) and generally accommodate only one or two people ( $86 \%$ of renter occupied units), they may not be contributing substantially to the resolution of the community's affordable housing challenge (Chappelle, 2021).

\title{
Updated Zoning Ordinance
}

All of the jurisdictions in Santa Clara County updated their zoning ordinances as required by state law. Specific information regarding zoning restrictions and requirements can be found in each local government's municipal code. Common zoning updates for each jurisdiction included a reduced minimum lot size requirement to build an ADU or no minimum lot size to build an ADU. Zoning was expanded to include multifamily zones for ADU construction. In addition to having an ADU, most jurisdictions will permit the construction of a junior ADU with a 
maximum floor space of 500 sq. ft. that can be attached to the primary dwelling unit or an ADU. The maximum floor area for ADUs was increased to 1,000 sq. $\mathrm{ft}$ or $1,200 \mathrm{sq}$. ft. in most jurisdictions. The minimum setback for the rear and sides of the homes was reduced to accommodate more housing types. Required parking for ADUs is now only necessary if the house is not within half a mile of public transportation; the parking spot can be in the form of street parking, driveway parking, or a garage. The approval process for ADUs and JADUs has been updated to be ministerial, which means that no discretionary approval with a public notice is required; only building permits and related permits are required to be approved. These updated zoning ordinances were adopted in all jurisdictions in Santa Clara County to reduce the restrictions and make ADUs available in various residential zones. This is done to increase in-fill development across the cities and create more opportunities for additional housing.

\section{ADU Program Webpage}

Every city in Santa Clara County has a dedicated webpage for its ADU program except for the City of Sunnyvale. Although dedicating a webpage to their ADU program was not required as a part of the new ADU laws, this is a helpful method that cities use to provide public information that details at a minimum general information about ADUs. Jurisdictions are required by the recent ADU laws to include a plan that encourages and promotes the building of ADUs that can be rented at affordable rates. Creating dedicated webpages for their ADU program is one way to inform the public and encourage ADU development. Other common information on each jurisdiction's webpage includes information on their updated zoning ordinances, potential fees, development standards, and design standards. Some of the cities in Santa Clara County also provided resources about possible state grant funding, fee waivers, architects, and additional information. This information benefits homeowners and developers interested in ADUs and who 
might need guidance on where to start. Having a web page is a helpful tool that provides data easily to the public and informs the public of benefits that an ADU may provide. It can provide a guideline for obtaining an ADU permit to the final approval steps.

\section{ADU Plan Review Checklist}

Throughout all of the jurisdictions in Santa Clara County, only the City of Cupertino, the City of Gilroy, the City of Los Altos, Town of Los Gatos, City of San Jose, and the City of Sunnyvale have an ADU plan review checklist that is provided publicly. Although this checklist is not required by law, it is convenient for homeowners, developers, and architects to refer to the provided checklist to ensure that they have completed all necessary steps to obtain a building permit. This checklist will help keep everyone involved in the planning process on track and will minimize delays. Other benefits of having a checklist are that it will reduce building permit review time, streamline the permitting process, and make the process smoother for homeowners and all departments involved in reviewing the building application. A plan review checklist will often include what is expected of formatting standards, site plans, mechanical and plumbing plans, grading plans, soil reports, Title 24 for energy-efficient standards, and other specific details required by that jurisdiction. These plan checklists are intended to show the most common code items reviewed during construction project plan reviews, and are beneficial for all parties involved.

\section{Updated Housing Element}

The Housing Element section of every jurisdiction's General Plan from the previous planning period mentions ADUs as a strategy to increase affordable housing. The jurisdictions in Santa Clara County all had their ADU program history. All of the jurisdictions in Santa Clara County recognize that housing affordability is an issue that California residents face. These cities have 
used ADUs as an approach to provide economic variety in their housing supply. Before the recent ADU laws passed, all of the cities in Santa Clara County had their specific plans to expand their ADU program to lessen its restrictions. The new state legislation supersedes each of the cities' provisions for ADUs and JADUs, but the cities are allowed to detail additional specific requirements that pertain to their city. It is expected that in the next Housing Element update for the next planning cycle, each of the local jurisdictions will include the updated state law regarding ADUs and how it has impacted ADU production in their jurisdiction.

\section{Incentive Programs}

There are various ways that the jurisdictions in Santa Clara County have provided incentives for homeowners to build ADUs. These incentives range from the recent ADU laws to make the permitting process of obtaining an ADU less strict to information on additional resources that homeowners can seek to help build their ADUs. Building an ADU can be intimidating and new to some people, and providing information and incentives to homeowners can ease the process for them and make the process less overwhelming.

Common incentives that jurisdictions provide include an amnesty program to allow illegally built ADUs to become legal by conforming to the building code. This will ensure that the ADU is safe to be occupied, and it can be added to the housing stock and city tax rolls. Another motivation is that there are no impact fee charges on ADUs that are less than 750 sq. $\mathrm{ft}$., which might appeal to homeowners as a cost saving. Some common trends in some jurisdictions were deed-restricted ADUs that were specifically for low and very low-income household categories of tenants. The City of Saratoga has a floor area and site coverage bonus provision of a 10 percent increase which is given when units are deed-restricted for below-market-rate tenants as an incentive for homeowners create affordable units (City of Saratoga, 2014). The Town of 
Los Altos Hills offers additional incentives for the additional floor area. If the junior ADU has an on-site parking space, it is allowed to exceed the 500 square feet maximum floor area by increasing to 650 square feet (Town of Los Altos Hills, 2020).

The City of San Jose offers pre-approved ADU plans with experienced vendors that homeowners can use for a faster and low-cost method to build ADUs. The Town of Los Gatos introduced a program to expand secondary dwelling units by allowing these dwelling units to be deed-restricted to offer rent at an affordable rate for lower-income renters (Town of Los Gatos, 2015). This will encourage affordable housing in areas that did not have affordable housing options previously. Other incentives to their secondary unit program included waiving application fees for these affordable units with funding from the Below Market Price Housing Inlieu Fee Program (Town of Los Gatos, 2015).

The City of Milpitas has a program called 'ADU Mondays' on their ADU webpage that provides residents with a consultation and resources to familiarize residents with their ADU program. The City of Monte Sereno waived fees for rent-restricted units and created an amnesty program for illegally built ADUs (City of Monte Sereno, 2015). These incentives can be incorporated into the jurisdiction's ADU programs to support homeowners' ADU construction and encourage more ADU production at an affordable rent.

\section{Progress Toward RHNA Goals}

In the 2015 to 2023 Housing Element for each of the jurisdictions, they all planned on crediting ADUs for their RHNA goals for the moderate-income, low-income, and very-low-income groups. Progress made toward these allocations is measured by the number of permits that each City has issued for each income group (Silicon Valley at Home, 2020-a). In the current trends for meeting each jurisdiction's RHNA goals, nearly every jurisdiction has met its housing needs for 
their above moderate-income level category or is on track to meeting its goal. Very few cities have met their low-income and very low-income categories. The cities that met the low-income categories so far were the City of Gilroy and City of Morgan Hill. The only city to meet the very low-income category was the City of Monte Sereno, as their RHNA goal for very low-income was 23, and as of 2019 they had issued 43 permits (Silicon Valley at Home, 2020-a).

In recent studies done in the San Francisco Bay Area and statewide, it was found that a considerable number of ADUs are leased to family (16\%), caretakers, and acquaintances (2\%) at reduced costs or no cost, or are used as offices or studios by the owners (16\%) (City of Palo Alto, 2017; Chapelle, 2021). These studies indicate that the other 2/3 of ADUs may be a source of inexpensive housing for local jurisdictions in Santa Clara County and nearby areas. One study found that present rental rates for ADUs are affordable for very-low-income, low-income, and moderate-income groups for two or three-person households (City of Palo Alto, 2017), however $86 \%$ of rented ADUs are single person or two person households (Chapelle, 2021). Therefore, the second units permitted thus far and future second units can be credited against the RHNA goals for very-low-income, low-income, and moderate-income groups. Jurisdictions should detail in their next Housing Element their specific strategies to encourage more ADU production to reach RHNA goals. 
Table 20: RHNA Permit Progress as of 2019

\begin{tabular}{|c|c|c|c|c|c|}
\hline \multicolumn{6}{|c|}{ 2015-2023 RHNA Permit Progress as of 2019} \\
\hline Jurisdiction & Affordability Level & $\begin{array}{c}\text { RHNA } \\
\text { Goal }\end{array}$ & $\begin{array}{c}\text { Permits as } \\
\text { of } 2019\end{array}$ & $\begin{array}{l}\text { Percent } \\
\text { Progress }\end{array}$ & $\begin{array}{c}\text { *Projected } \\
\text { Final }\end{array}$ \\
\hline \multirow{5}{*}{ Campbell } & Very Low Income & 253 & 11 & $4 \%$ & $6 \%$ \\
\hline & Low Income & 138 & 4 & $3 \%$ & $4 \%$ \\
\hline & Moderate Income & 151 & 16 & $11 \%$ & $15 \%$ \\
\hline & Above Moderate & 391 & 407 & $104 \%$ & $144 \%$ \\
\hline & Total & 933 & 438 & $47 \%$ & $65 \%$ \\
\hline \multirow[t]{5}{*}{ Cupertino } & Very Low Income & 356 & 19 & $5 \%$ & $7 \%$ \\
\hline & Low Income & 207 & 0 & $0 \%$ & $0 \%$ \\
\hline & Moderate Income & 231 & 74 & $32 \%$ & $44 \%$ \\
\hline & Above Moderate & 270 & 215 & $80 \%$ & $110 \%$ \\
\hline & Total & 1064 & 308 & $29 \%$ & $40 \%$ \\
\hline \multirow[t]{5}{*}{ Gilroy } & Very Low Income & 236 & 63 & $27 \%$ & $37 \%$ \\
\hline & Low Income & 160 & 487 & $304 \%$ & $420 \%$ \\
\hline & Moderate Income & 217 & 24 & $11 \%$ & $15 \%$ \\
\hline & Above Moderate & 475 & 1124 & $237 \%$ & $327 \%$ \\
\hline & Total & 1088 & 1698 & $156 \%$ & $215 \%$ \\
\hline \multirow[t]{5}{*}{ Los Altos } & Very Low Income & 169 & 2 & $1 \%$ & $2 \%$ \\
\hline & Low Income & 99 & 28 & $28 \%$ & $39 \%$ \\
\hline & Moderate Income & 112 & 2 & $2 \%$ & $2 \%$ \\
\hline & Above Moderate & 97 & 535 & $552 \%$ & $761 \%$ \\
\hline & Total & 477 & 567 & $119 \%$ & $164 \%$ \\
\hline \multirow[t]{5}{*}{ Los Altos Hills } & Very Low Income & 46 & 13 & $28 \%$ & $39 \%$ \\
\hline & Low Income & 28 & 5 & $18 \%$ & $25 \%$ \\
\hline & Moderate Income & 32 & 4 & $13 \%$ & $17 \%$ \\
\hline & Above Moderate & 15 & 38 & $253 \%$ & $350 \%$ \\
\hline & Total & 121 & 60 & $50 \%$ & $68 \%$ \\
\hline \multirow[t]{5}{*}{ Los Gatos } & Very Low Income & 201 & 0 & $0 \%$ & $0 \%$ \\
\hline & Low Income & 112 & 2 & $2 \%$ & $2 \%$ \\
\hline & Moderate Income & 132 & 53 & $40 \%$ & $55 \%$ \\
\hline & Above Moderate & 174 & 79 & $45 \%$ & $63 \%$ \\
\hline & Total & 619 & 134 & $22 \%$ & $30 \%$ \\
\hline \multirow[t]{5}{*}{ Milpitas } & Very Low Income & 1004 & 10 & $1 \%$ & $1 \%$ \\
\hline & Low Income & 570 & 0 & $0 \%$ & $0 \%$ \\
\hline & Moderate Income & 565 & 0 & $0 \%$ & $0 \%$ \\
\hline & Above Moderate & 1151 & 3221 & $280 \%$ & $386 \%$ \\
\hline & Total & 3290 & 3231 & $98 \%$ & $136 \%$ \\
\hline \multirow[t]{5}{*}{ Monte Sereno } & Very Low Income & 23 & 43 & $187 \%$ & $258 \%$ \\
\hline & Low Income & 13 & 1 & $8 \%$ & $11 \%$ \\
\hline & Moderate Income & 13 & 1 & $8 \%$ & $11 \%$ \\
\hline & Above Moderate & 12 & 30 & $250 \%$ & $345 \%$ \\
\hline & Total & 61 & 75 & & $170 \%$ \\
\hline
\end{tabular}

Source: HCD 2019 Annual Progress Report Permit Summary provided by Silicon Valley at Home 
Table 21: RHNA Permit Progress as of 2019

\begin{tabular}{|c|c|c|c|c|c|}
\hline Morgan Hill & $\begin{array}{l}\text { Very Low Income } \\
\text { Low Income } \\
\text { Moderate Income } \\
\text { Above Moderate } \\
\text { Total }\end{array}$ & $\begin{array}{l}273 \\
154 \\
185 \\
316 \\
928\end{array}$ & $\begin{array}{r}41 \\
165 \\
136 \\
1200 \\
1542\end{array}$ & $\begin{array}{r}15 \% \\
107 \% \\
74 \% \\
380 \% \\
166 \%\end{array}$ & $\begin{array}{r}21 \% \\
148 \% \\
101 \% \\
524 \% \\
229 \%\end{array}$ \\
\hline Mountain View & $\begin{array}{l}\text { Very Low Income } \\
\text { Low Income } \\
\text { Moderate Income } \\
\text { Above Moderate } \\
\text { Total }\end{array}$ & $\begin{array}{r}814 \\
492 \\
527 \\
1093 \\
2926 \\
\end{array}$ & $\begin{array}{r}202 \\
170 \\
0 \\
3223 \\
3595\end{array}$ & $\begin{array}{r}25 \% \\
35 \% \\
0 \% \\
295 \% \\
123 \% \\
\end{array}$ & \begin{tabular}{r|}
$34 \%$ \\
$48 \%$ \\
$0 \%$ \\
$407 \%$ \\
$170 \%$ \\
\end{tabular} \\
\hline Palo Alto & $\begin{array}{l}\text { Very Low Income } \\
\text { Low Income } \\
\text { Moderate Income } \\
\text { Above Moderate } \\
\text { Total }\end{array}$ & $\begin{array}{r}691 \\
432 \\
278 \\
587 \\
1988 \\
\end{array}$ & $\begin{array}{r}43 \\
60 \\
42 \\
409 \\
554 \\
\end{array}$ & $\begin{array}{r}6 \% \\
14 \% \\
15 \% \\
70 \% \\
28 \% \\
\end{array}$ & $\begin{array}{r}9 \% \\
19 \% \\
21 \% \\
96 \% \\
38 \%\end{array}$ \\
\hline San Jose & $\begin{array}{l}\text { Very Low Income } \\
\text { Low Income } \\
\text { Moderate Income } \\
\text { Above Moderate } \\
\text { Total }\end{array}$ & $\begin{array}{r}9233 \\
5428 \\
6188 \\
14231 \\
35080 \\
\end{array}$ & $\begin{array}{r}1129 \\
231 \\
2304 \\
13392 \\
17056 \\
\end{array}$ & $\begin{array}{r}12 \% \\
4 \% \\
37 \% \\
94 \% \\
49 \% \\
\end{array}$ & \begin{tabular}{r|}
$17 \%$ \\
$6 \%$ \\
$51 \%$ \\
$130 \%$ \\
$67 \%$ \\
\end{tabular} \\
\hline Santa Clara & $\begin{array}{l}\text { Very Low Income } \\
\text { Low Income } \\
\text { Moderate Income } \\
\text { Above Moderate } \\
\text { Total }\end{array}$ & $\begin{array}{r}1050 \\
695 \\
755 \\
1593 \\
4093 \\
\end{array}$ & $\begin{array}{r}131 \\
16 \\
54 \\
4008 \\
4209 \\
\end{array}$ & $\begin{array}{r}12 \% \\
2 \% \\
7 \% \\
252 \% \\
103 \% \\
\end{array}$ & \begin{tabular}{|r|}
$17 \%$ \\
$3 \%$ \\
$10 \%$ \\
$347 \%$ \\
$142 \%$ \\
\end{tabular} \\
\hline Santa Clara Coun & $\begin{array}{l}\text { Very Low Income } \\
\text { Low Income } \\
\text { Moderate Income } \\
\text { Above Moderate } \\
\text { Total }\end{array}$ & $\begin{array}{r}22 \\
13 \\
214 \\
28 \\
277\end{array}$ & $\begin{array}{r}88 \\
0 \\
2597 \\
268 \\
2953 \\
\end{array}$ & $\begin{array}{r}400 \% \\
0 \% \\
1214 \% \\
957 \% \\
1066 \%\end{array}$ & $\begin{array}{r}552 \% \\
0 \% \\
1675 \% \\
1321 \% \\
1471 \%\end{array}$ \\
\hline Saratoga & $\begin{array}{l}\text { Very Low Income } \\
\text { Low Income } \\
\text { Moderate Income } \\
\text { Above Moderate } \\
\text { Total }\end{array}$ & $\begin{array}{r}147 \\
95 \\
104 \\
93 \\
439\end{array}$ & $\begin{array}{r}0 \\
49 \\
14 \\
22 \\
85\end{array}$ & $\begin{array}{r}0 \% \\
52 \% \\
13 \% \\
24 \% \\
19 \% \\
\end{array}$ & \begin{tabular}{r|}
$0 \%$ \\
$71 \%$ \\
$19 \%$ \\
$33 \%$ \\
$27 \%$ \\
\end{tabular} \\
\hline Sunnyvale & $\begin{array}{l}\text { Very Low Income } \\
\text { Low Income } \\
\text { Moderate Income } \\
\text { Above Moderate } \\
\text { Total }\end{array}$ & $\begin{array}{r}1640 \\
906 \\
932 \\
1974 \\
\mathbf{5 4 5 2}\end{array}$ & $\begin{array}{r}114 \\
21 \\
207 \\
2215 \\
2557\end{array}$ & \begin{tabular}{r|}
$7 \%$ \\
$2 \%$ \\
$22 \%$ \\
$112 \%$ \\
$47 \%$
\end{tabular} & \begin{tabular}{|r|}
$10 \%$ \\
$3 \%$ \\
$31 \%$ \\
$155 \%$ \\
$65 \%$ \\
\end{tabular} \\
\hline
\end{tabular}

Source: HCD 2019 Annual Progress Report Permit Summary provided by Silicon Valley at Home 
Table 22: 2016-2020 Issued ADU Permit Totals

\begin{tabular}{|l|c|c|c|c|c|c|}
\hline \multirow{2}{*}{ City/Jurisdiction } & $\mathbf{2 0 1 6}$ & $\mathbf{2 0 1 7}$ & $\mathbf{2 0 1 8}$ & $\mathbf{2 0 1 9}$ & $\mathbf{2 0 2 0}$ & Total \\
\cline { 2 - 7 } & Issued & Issued & Issued & Issued & Issued & Issued \\
\hline Campbell & $\mathrm{N} / \mathrm{A}$ & $\mathrm{N} / \mathrm{A}$ & $\mathrm{N} / \mathrm{A}$ & $\mathrm{N} / \mathrm{A}$ & 40 & 40 \\
\hline Cupertino & $\mathrm{N} / \mathrm{A}$ & 1 & 7 & 11 & 16 & 35 \\
\hline Gilroy & 4 & 7 & 7 & 11 & 13 & 42 \\
\hline Los Altos & 2 & 3 & 9 & 31 & 22 & 67 \\
\hline Los Altos Hills & $\mathrm{N} / \mathrm{A}$ & $\mathrm{N} / \mathrm{A}$ & $\mathrm{N} / \mathrm{A}$ & $\mathrm{N} / \mathrm{A}$ & $\mathrm{N} / \mathrm{A}$ & 0 \\
\hline Los Gatos & 1 & 3 & 4 & 8 & 6 & 22 \\
\hline Milpitas & 7 & 6 & 16 & 37 & 8 & 74 \\
\hline Monte Sereno & $\mathrm{N} / \mathrm{A}$ & $\mathrm{N} / \mathrm{A}$ & $\mathrm{N} / \mathrm{A}$ & $\mathrm{N} / \mathrm{A}$ & $\mathrm{N} / \mathrm{A}$ & 0 \\
\hline Morgan Hill & 2 & 5 & 15 & 10 & 4 & 36 \\
\hline Mountain View & $\mathrm{N} / \mathrm{A}$ & 1 & 8 & 12 & 16 & 37 \\
\hline Palo Alto & 5 & 12 & 35 & 62 & 13 & 127 \\
\hline San Jose & 39 & 94 & 189 & 415 & 377 & 1114 \\
\hline Santa Clara & 4 & 15 & 20 & 30 & 31 & 100 \\
\hline Santa Clara County & 2 & 3 & 27 & 34 & 53 & 119 \\
\hline Saratoga & 13 & 20 & 12 & 27 & 39 & 111 \\
\hline Sunnyvale & 3 & 4 & 21 & 44 & 45 & 117 \\
\hline
\end{tabular}

In Santa Clara County, affordability for secondary dwelling units is based on a survey of homeowners with ADUs. The findings of this survey were that the majority of ADUs are occupied by families that pay no rent, and the remaining paid an average rent of $\$ 1,700$ (County of Santa Clara, 2014). These results are comparable with surveys of ADU rents from surrounding areas that imply that many of these ADUs are rented at reasonable rates or no cost to family members, acquaintances, or workers employed by the family (County of Santa Clara, 2014).

The number of ADU permits issued has been increasing steadily since 2016 . There was a jump in ADU permits in most jurisdictions starting in 2018, which may be due to eased restrictions for ADU permitting. Although there have been increases to ADU permits from 2016 to 2020 , the totals so far are still not enough for some jurisdictions to meet their very-low, low, 
and moderate-income groups. While the ADU permits issued can be credited for RHNA allocation for moderate, low, and very-low-income groups, jurisdictions will have to improve their ADU program and explore other methods for housing if they want to reach their RHNA goals. By the end of this RHNA period, some jurisdictions may get close to their goals, as ADUs are expected to be increased even more in the next few years. Once the work from home mandates related to OVID-19 are over, some of the home office uses may turn into residential units and become part of the affordable housing stock (Chapelle, 2021).

\section{Limitations}

Some limitations to this research include insufficient data from some of the jurisdictions that were researched. Some of the cities that were contacted could not produce an accurate report that detailed the number of ADU permits issued and finaled from 2016 to 2020. Other cities were not responsive to any requests for data, or there were no public data for issued building permits. There may be some discrepancies with the data displayed compared to the jurisdiction's official data. This is due to lack of information provided by the jurisdiction, human error with crossreferencing the data provided with the jurisdiction's database of finaled permits, or insufficient public data. This study was done based on recent ADU laws that went into effect on January 1, 2020. Therefore, it might be too soon to see whether the ADU permits issued in 2020 were in response to these laws.

It is also challenging to determine what specific factors of the law have increased ADU permits. Another limitation to the research was the Covid-19 pandemic. There is a possibility that the data for 2020 may be skewed due to the state-wide stay-at-home orders, office closure, delays in construction, and increased construction costs due to the pandemic. 


\section{CONCLUSION}

The ADU laws that were passed in California, effective January 1, 2020, were designed to increase the housing stock with the limited developed land available by allowing ADUs and expanding the criteria under which ADUs are allowed. The research suggests that ADUs tend to be rented at affordable rates and can be added toward RHNA goals for each city. Other findings indicated an increasing trend in ADU permits issued and finaled that align with the changing ADU laws intended to promote ADU production.

There is a stark difference between issued building permits for ADUs compared to finaled permits for ADUs. Homeowners will have to act as a developer when building ADUs, and this can be a daunting experience to some, which might deter them from inquiring about ADUs. The lack of finalized ADUs can be due to several factors, such as cost of construction, fees, financing challenges, building permits expiring, and lack of motivation for homeowners. Cities can implement additional incentives to encourage homeowners to complete the building of their ADUs by alleviating some of the costs by offering impact fee waivers, density bonuses and adding something as simple as a plan checklist review to streamline the process for homeowners.

It is anticipated that the numbers for ADU permits will continue to increase as the laws keep updating. Local governments can also create educational outreach programs to inform the public about eligibility for ADUs to make the experience less intimidating, and provide homeowners with additional resources to assist with design, construction, and financing. State law and HCD can provide technical guidance documents to cities for a streamlined process to credit ADUs toward RHNA goals. Cities can use the findings and analysis from this research to implement new approaches to their ADU programs that can be used in their Housing Element. These strategies can streamline their program and apply different methods to encourage more 
ADUs. ADUs are one method to increase the inadequate housing stock and promote affordable housing in areas that did not have affordable housing options previously. Local jurisdictions now have another way to increase variety in their housing stock and provide affordable housing to all income categories.

\section{Areas for Future Research}

This same research can be conducted in future years to determine which methodology works best to incentivize the construction of ADUs and the extent to which it is achieving RHNA goals.

Due to the Covid-19 pandemic, the data for issued and finaled ADUs may be skewed, so conducting this research in the future might give a better indication of the success of the new ADU laws. Another interesting area of research will be to see whether areas with higher resources have a higher rate of ADUs being completed, being that some of the most significant barriers for ADU development are financing and costs. Other research that can be conducted is a survey of homeowners with ADUs to determine what factors motivated them to build their ADU and their thoughts on the recent ADU laws. 


\section{REFERENCES}

A.B. 68, 2019-2020 Reg. Sess. (Cal. 2019) (enacted).

https://leginfo.legislature.ca.gov/faces/billTextClient.xhtml?bill_id=201920200AB68

A.B. 670, 2019-2020 Reg. Sess. (Cal. 2019) (enacted).

https://leginfo.legislature.ca.gov/faces/billTextClient.xhtml?bill_id=201920200AB670

A.B. 2299, 2015-2016 Reg. Sess. (Cal. 2016) (enacted).

https://leginfo.legislature.ca.gov/faces/billNavClient.xhtml?bill_id=201520160AB2299

A.B. 2406, 2015-2016 Reg. Sess. (Cal. 2016) (enacted).

https://leginfo.legislature.ca.gov/faces/billNavClient.xhtml?bill_id=201520160AB2406

Basor, I.N. (2020). Creating Accessory Dwelling Units (ADUs) During the California housing shortage: benchmarking ADU programs within selected Bay Area city and county jurisdictions against the City of the Santa Cruz and the County of Santa Cruz. (Publication number 938) [Master’s research project, San Jose State University] https://scholarworks.sjsu.edu/etd_projects/938

Best, Best \& Krieger. (2020). California Supreme Court Clarifies Ministerial vs. Discretionary Actions Under CEQA for Well Construction Permits. BB\&K Legal Alerts, September 1. https://www.bbklaw.com/news-events/insights/2020/legal-alerts/09/california-supreme$\underline{\text { court-clarifies-ministerial-vs }}$ 
Bhatt, N., \& Ryan, M. (2015). Model Policy: Accessory Dwelling Units in Santa Cruz. Local Leaders Council, Smart Growth America. http://www.smartgrowthusa.org/documents/Accessory_Dwelling_Santa_Cruz_Ordinance $\underline{. p d} \mathrm{f}$

Brinig, M. F., \& Garnett, N. S. (2013). A room of one's own? Accessory dwelling unit reforms and local parochialism. The Urban Lawyer, 45(3), 519-569. https://scholarship.law.nd.edu/law_faculty_scholarship/286/

Cal. Gov. $\S 65852.2$. (n.d.). https://leginfo.legislature.ca.gov/faces/codes_displaySection.xhtml?sectionNum=65852.2. $\underline{\& l a w \text { Code }=\mathrm{GOV}}$

California Department of Housing and Community Development - HCD. (n.d.-a). Accessory Dwelling Units (ADUs) and Junior Accessory Dwelling Units (JADUs). HCD. https://www.hcd.ca.gov/policy-research/accessorydwellingunits.shtml

California Department of Housing and Community Development- HCD. (2018). California's housing Future: challenges and opportunities final statewide housing assessment 2025. HCD. https://www.hcd.ca.gov/policy-research/plansreports/docs/sha maindoc 2 _ 15 final.pdf

California Department of Housing and Community Development - HCD. (n.d.-b). Projected housing needs- Regional Housing Needs Allocation. HCD. https://www.hcd.ca.gov/community-development/building-blocks/housingneeds/projected-housing-needs.shtml 
California Department of Housing and Community Development - HCD. (n.d.-c). Regional Housing Needs Allocation and Housing Elements. HCD https://www.hcd.ca.gov/community-development/housing-element/index.shtml

California Modulars. (n.d.). Cost \& Financing: ADU's, pre-fab ADU's, backyard offices, tiny homes, Bay Area, Northern California. California Modulars. https://californiamodulars.com/costs-financing/

Chapple, K., Ganetsos, D. and Lopez, E. (2021). Implementing the Backyard Revolution: Perspectives of California's ADU Owners. UC Berkeley Center for Community Innovation. https://www.aducalifornia.org/wp-content/uploads/2021/04/Implementingthe-Backyard-Revolution.pdf

Chapple, K., Garcia, D., Valchuis, E., and Tucker, J. (2020). Reaching California's ADU potential: progress to date and the need for ADU finance. Terner Center and Center for Community Innovation Report. https://ternercenter.berkeley.edu/research-andpolicy/reaching-californias-adu-potential-progress-to-date-and-the-need-for-adu-finance/

Chapple, K., Wegmann, J., Nemirow, A., and Dentel-Post, C. (2012). Yes in my backyard: mobilizing the market for secondary units. The Center for Community Innovation. https://communityinnovation.berkeley.edu/sites/default/files/yes_in_my_backyard_mobil izing the_market_for_secondary_units.pdf?width $=1200 \&$ height $=800 \&$ iframe $=$ true

CCI. (n.d.). California ADU. The Center for Community Innovation (CCI) at UC Berkeley. https://www.aducalifornia.org/about/ 
City of Campbell. (2015). General Plan. Retrieved from

https://www.ci.campbell.ca.us/DocumentCenter/View/2664/General-Plan-2015

City of Campbell. (2020). ADU summary sheet. Retrieved from

https://www.ci.campbell.ca.us/DocumentCenter/View/14449/ADU-Summary-Sheet

City of Cupertino. (2015). General Plan. Retrieved from

https://records.cupertino.org/WebLink/docview.aspx?dbid=0\&id=873201\&repo=CityofC upertino\&cr $=1$

City of Cupertino. (2020). Accessory dwelling unit information sheet. Retrieved from https://www.cupertino.org/home/showpublisheddocument/28560/637405997048300000

City of Gilroy. (2020-a). Accessory dwelling units. Retrieved from http://www.cityofgilroy.org/903/Accessory-Dwelling-Units

City of Gilroy. (2020-b). General Plan 2040. Retrieved from http://www.cityofgilroy.org/DocumentCenter/View/11309/Gilroy-2040-General-Plan-39MB?bidId=

City of Gilroy. (2014). Housing Element. Retrieved from http://www.cityofgilroy.org/DocumentCenter/View/5272/Housing-Element-2015-2023

City of Los Altos. (2015). Housing Element. Retrieved from https://www.losaltosca.gov/sites/default/files/fileattachments/community_development/p age/39021/2015-2023_los_altos_housing_element_final.pdf 
City of Los Altos. (2020). Code of Ordinances. Retrieved from https://ibrary.municode.com/ca/los_altos/codes/code_of ordinances?nodeId=TIT14ZO CH14.14ACDWUN

City of Milpitas. (2020). Accessory dwelling units zoning. Retrieved from https://library.municode.com/ca/milpitas/codes/code_of_ordinances?nodeId=TITXIZOP LAN_CH10ZO_S13SPUS_XI-10-13.08ACDWUN

City of Milpitas. (2015). Housing Element. Retrieved from http://www.ci.milpitas.ca.gov/_pdfs/AdoptedHousingElement2015-2023.pdf

City of Monte Sereno. (2020). Accessory Dwelling Unit (ADU) handbook. Retrieved from https://cityofmontesereno.org/DocumentCenter/View/3108/Accessory-Dwelling-UnitADU-Handbook

City of Monte Sereno. (2015). General Plan. Retrieved from https://cityofmontesereno.org/DocumentCenter/View/1397/General-Plan

City of Morgan Hill. (2016). General Plan. Retrieved from

https://www.morgan-hill.ca.gov/DocumentCenter/View/22839/MH2035-General-Plan--December-2017?bidId=

City of Morgan Hill. (n.d.). Accessory dwelling units. Retrieved from https://www.morgan-hill.ca.gov/99/Accessory-Dwelling-Units-ADUs

City of Mountain View. (2014). Housing Element. Retrieved from 
https://www.mountainview.gov/civicax/filebank/blobdload.aspx?BlobID=15284

City of Mountain View. (2020). Informational guide for accessory dwelling units and junior accessory dwelling units. Retrieved from https://www.mountainview.gov/civicax/filebank/blobdload.aspx?BlobID=33767

City of Palo Alto. (2017). City of Palo Alto comprehensive plan 2030. Retrieved from https://www.cityofpaloalto.org/files/assets/public/planning-amp-development-services/3.comprehensive-plan/comprehensive-plan/paloaltocompplan_2017_pdf_w_links.pdf

City of Palo Alto. (2020). Item \#8: accessory dwelling units. City Council City of Palo Alto. Retrieved from https://www.cityofpaloalto.org/files/assets/public/agendas-minutesreports/reports/city-manager-reports-cmrs/current-year/2020/10052020-item-8presentation.pdf

City of San Jose. (n.d.). Accessory dwelling units (ADUs). City of San Jose. Retrieved from https://www.sanjoseca.gov/business/development-services-permit-center/accessorydwelling-units-adus

City of San Jose. (2015, January 27). City of San José 2014-2023 Housing Element. City of San Jose. Retrieved from https://www.sanjoseca.gov/home/showpublisheddocument?id=16025

City of Santa Clara. (n.d.) City of Santa Clara Housing Element 2015-2023. City of Santa Clara General Plan. Retrieved from https://www.santaclaraca.gov/home/showpublisheddocument?id=13932 
City of Saratoga. (2014, November 19). 2015-2023 Housing Element. City of Saratoga.

Retrieved from https://www.saratoga.ca.us/DocumentCenter/View/45/Housing-Element2015---2023-Dated-November-2014-PDF

City of Saratoga. (n.d.). Accessory dwelling units. City of Saratoga. Retrieved from https://www.saratoga.ca.us/439/Accessory-Dwelling-Units

City of Sunnyvale. (2014, December 16). Housing Element of the General Plan January 31, 2015- January 31, 2023. City of Sunnyvale. Retrieved from https://sunnyvale.ca.gov/civicax/filebank/blobdload.aspx?BlobID=23978

City of Sunnyvale. (2021). Sunnyvale homeowners: interested in building an Accessory Dwelling Unit? City of Sunnyvale. Retrieved from https://sunnyvale.ca.gov/civicax/filebank/blobdload.aspx?BlobID=23584

County of Santa Clara. (2020, March 10). ADU changes and FAQs. County of Santa Clara Department of Planning and Development. Retrieved from https://www.sccgov.org/sites/dpd/DocsForms/Documents/ADU_FAQ.pdf

County of Santa Clara. (2014, June 10). Housing Element Update 2015-2022. County of Santa Clara. Retrieved from https://stgenpln.blob.core.windows.net/document/HousingElement_2015_Adopted_Final. pdf

Davis, A. (2018). The tiny house solution: accessory dwelling units as a housing market fix. Harvard Kennedy School Review, 18, 145-152. 
https://ksr.hkspublications.org/2018/09/04/the-tiny-house-solution-accessory-dwellingunits-as-a-housing-market-fix/

DeRuy, E. (2019, May 16). Mayor proposes granny flat program to boost housing. The Mercury News. Retrieved from https://infoweb.newsbank.com/resources/doc/nb/news/173833E9C8EA7498?p=NewsBan $\underline{\mathrm{k}}$

Garcia, D. (2017, December 21). ADU update: early lessons and impacts of California's state and local policy changes. Terner Center for Housing Innovation. Terner Center for Housing Innovation UC Berkeley. Retrieved from https://ternercenter.berkeley.edu/research-and-policy/adu-update-early-lessons-andimpacts-of-californias-state-and-local-policy-changes/

Housing Trust Silicon Valley. (n.d.). Small homes, big impact. Housing Trust Silicon Valley. Retrieved from https://housingtrustsv.org/programs/homeowner-programs/accessorydwelling-unit-program/

Kimberlin, S. (2019, April). California's housing affordability crisis hits renters and households with the lowest incomes the hardest. California Budget \& Policy Center. Retrieved from https://calbudgetcenter.org/resources/californias-housing-affordability-crisis-hits-rentersand-households-with-the-lowest-incomes-the-hardest/

Koones, S. (2019, February 6). The rise of accessory dwelling units in the U.S. and Canada. Forbes. Retrieved from https://www.forbes.com/sites/sherikoones/2019/02/06/the-rise-ofaccessory-dwelling-units-in-the-u-s-and-canada/ 
Lopez, N. (2020, January 7). Update: San Jose approves amnesty program for illegal granny units. San Jose Spotlight. Retrieved from https://sanjosespotlight.com/granny-flatprogram-aims-to-help-ease-housing-shortage/

Maclean, C., Golub, D., \& Ashe, K. (2019, November 2). California's 2020 housing laws: what you need to know. Insights. Retrieved from https://www.hklaw.com/en/insights/publications/2019/10/californias-2020-housing-laws what-you-need-to-know

Murphy, A. (2019, October 22). New California law restricts municipalities' ability to limit housing. California Land Use \& Development Law Report. Retrieved from https://www.californialandusedevelopmentlaw.com/2019/10/22/new-california-lawrestricts-municipalities-ability-to-limit-housing/

O'Donnell, J. D. (2016). Affordable housing ordinances: exactions or use restrictions in the postKoontz era. An analysis of California building industry association v. City of San Jose. Urban Lawyer, 48(4), 899-937. https://www.americanbar.org/groups/state_local_government/publications/urban_lawyer/ 2016/48-4/affordable-housing/

Ramsey-Musolf, D. (2018, September 18). Accessory dwelling units as low-income housing: California's Faustian bargain. Urban Science, 2(3), 89. https://doi.org/10.3390/urbansci2030089

Sanchez-Moyano, R., Galante, C. (2016, August 3). Small houses, big impact: accessory dwelling units in underutilized neighborhoods. Terner Center for Housing Innovation. 
Retrieved from https://ternercenter.berkeley.edu/research-and-policy/small-houses-bigimpact-making-the-case-for-accessory-dwelling-units-in-und/

San Francisco Planning and Urban Research Association. (2006, June 1). Secondary units: a painless way to increase the supply of housing. Spur. Retrieved from https://www.spur.org/publications/spur-report/2006-06-01/secondary-units

S.B. 13, 2019-2020 Reg. Sess. (Cal. 2019) (enacted). https://leginfo.legislature.ca.gov/faces/billNavClient.xhtml?bill_id=201920200SB13

S.B. 229, 2017-2018 Reg. Sess. (Cal. 2017) (enacted).

https://leginfo.legislature.ca.gov/faces/billTextClient.xhtml?bill_id=201720180SB229

S.B. 1069, 2015-2016 Reg. Sess. (Cal. 2016) (enacted).

https://leginfo.legislature.ca.gov/faces/billTextClient.xhtml?bill_id=201520160SB1069

Silicon Valley at Home. (2020, June 30-a). Regional Housing Need Allocation (RHNA). SV at Home. Retrieved from https://siliconvalleyathome.org/resource-map/regional-housingneed-allocation-rhna/

Silicon Valley at Home. (2020, September 23-b). RHNA Methodology. SV at Home. Retrieved from https://siliconvalleyathome.org/rhna-methodology/

Skinner, T. (2011). Accessory dwelling units and accessory Structures in Olympia, WA [Master's Thesis Project, Evergreen State College]. Retrieved from http://archives.evergreen.edu/masterstheses/Accession86 10MES/Skinner_TMESthesis2011.pdf 
Sylvia, R. D., \& Sylvia, K. M. (2012). Program Planning and Evaluation for The Public Manager. Long Grove, Illinois: Waveland Press.

Thompson, R. (2009). Somewhere in between: the classification and standard of review of mixed ministerial-discretionary land use decisions. Hastings Environmental Law Journal, 15(2), $325-346$.

https://repository.uchastings.edu/hastings_environmental_law_journal/vol15/iss2/7

Town of Los Altos Hills. (2015). Housing Element. Retrieved from

https://www.losaltoshills.ca.gov/DocumentCenter/View/153/General-Plan---5-Housing$\underline{\text { PDF? bidId }=}$

Town of Los Altos Hills. (2020). Accessory Dwelling Unit Ordinance. Retrieved from https://losaltoshills.ca.gov/DocumentCenter/View/4242/Updated-ADUOrdinance?bidId $=$

Town of Los Gatos. (2015). Housing Element. Retrieved from https://www.losgatosca.gov/DocumentCenter/View/14782/2015-2023-Adopted-LosGatos-Housing-Element-May-2015?bidId=

Town of Los Gatos. (2020). Ordinance 2307. Retrieved from http://weblink.losgatosca.gov/weblink/DocView.aspx?dbid=0\&id=1158276\&page=1\&cr $=1$

U.S Department of Housing and Urban Development - HUD. (2008). Accessory dwelling units: case study. Office of Policy Development and Research. Retrieved from https://www.huduser.gov/portal/publications/adu.pdf 